\title{
Secondary organic aerosol production from modern diesel engine emissions
}

\author{
S. Samy and B. Zielinska \\ Division of Atmospheric Sciences, Desert Research Institute, 2215 Raggio Pkwy., Reno, NV 89512, USA
}

Received: 24 July 2009 - Published in Atmos. Chem. Phys. Discuss.: 27 August 2009

Revised: 5 January 2010 - Accepted: 7 January 2010 - Published: 22 January 2010

\begin{abstract}
Secondary organic aerosol (SOA) production was observed at significant levels in a series of modern diesel exhaust (DE) aging experiments conducted at the European Outdoor Photoreactor/Simulation Chamber (EUPHORE). The greatest production occurred in DE with toluene addition experiments ( $>40 \%)$, followed by DE with $\mathrm{HCHO}$ (for $\mathrm{OH}$ radical generation) experiments. A small amount of SOA (3\%) was observed for DE in dark with $\mathrm{N}_{2} \mathrm{O}_{5}$ (for $\mathrm{NO}_{3}$ radical production) experiments. The analysis for a limited number (54) of polar organic compounds (POC) was conducted to assess the composition of modern DE and the formation of photochemical transformation products. Distinct POC formation in light versus dark experiments suggests the role of $\mathrm{OH}$ initiated reactions in these chamber atmospheres. A trend of increasing concentrations of dicarboxylic acids in light versus dark experiments was observed when evaluated on a compound group basis. The four toluene addition experiments in this study were performed at different $[\text { tol }]_{\mathrm{o}} /\left[\mathrm{NO}_{\mathrm{x}}\right]_{\mathrm{o}}$ ratios and displayed an average SOA $\%$ yield (in relation to toluene) of $5.3 \pm 1.6 \%$, which is compared to past chamber studies that evaluated the impact of $[\text { tol }]_{\mathrm{o}} /\left[\mathrm{NO}_{\mathrm{x}}\right]_{\mathrm{o}}$ on SOA production in more simplified mixtures.
\end{abstract}

\section{Introduction}

Oxidation of hydrocarbons from biogenic sources contributes to the major fraction of secondary organic aerosol (SOA) in the global atmosphere (Griffin et al., 1999; Szidat et al., 2004). Yet anthropogenic SOA is thought to contribute significantly to the total aerosol mass in urban/downwind urban areas, and may contribute up to one third of global

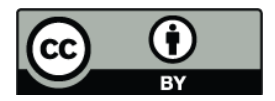

Correspondence to: $\mathrm{B}$. Zielinska (Barbara.Zielinska@dri.edu)
SOA (Volkamer et al., 2006). It has recently been suggested that underestimation of SOA formation in models is in part due to the oxidation of uncharacterized semivolatile organic compounds (SVOC) from vehicle emissions (Robinson et al., 2007; Weitkamp et al., 2007). Primary diesel exhaust (DE) is a complex mixture, composed of hundreds of organic and inorganic compounds in both gas and particle phases (Sagebiel et al., 1996; Zielinska et al., 2004a, b). The physical and chemical transformations of primary DE in the atmosphere are a concern for both human health and climate regulation purposes (Seinfeld and Pandis, 1998; Zielinska, 2005).

Although a number of laboratory studies have been carried out to elucidate the photochemical and oxidative processes that could lead to SOA formation (Kamens et al., 1981, 1982; Stern et al., 1987; Pandis et al., 1991; Forstner et al., 1997; Kleindienst et al., 2002, 2004; Kroll, 2006), most of these studies have focused on single precursor compounds or simplified chemical mixtures investigated in simulation chamber experiments with or without inorganic seed particles (such as ammonium sulfate). For example, the reaction of aromatic and polycyclic aromatic hydrocarbons (PAH) that are important constituents of motor vehicle emissions, have been studied in a series of photochemical chamber experiments (Zielinska et al., 1989a, b; Atkinson and Arey, 1994; Arey, 1998; Volkamer et al., 2001; Johnson, 2004, 2005; Martin and Wirtz, 2005; Hamilton et al., 2005; Gomez Alvarez et al., 2007). A comparison of these laboratory studies with results obtained from analysis of ambient aerosol particles is not straightforward, and discrepancies in results (e.g. aerosol yields and partitioning) may be attributed to the more simple chemical mixture and aerosol matrices in which these reactions occur, compared to those in the real atmosphere (Graber and Rudich, 2006). Thus, there is a need to investigate transformation processes of real mixtures arising from various combustion processes such as DE (Kroll and Seinfeld, 2008). 
Atmospheric transformations of DE and associated SOA production was examined in a set of experiments carried out in Valencia, Spain, with the aid of the European Photoreactor (EUPHORE) outdoor simulation chamber. The specific aims of this study were to characterize the gas and particle phase products of atmospheric transformations of modern diesel engine emissions under the influence of sunlight, ozone, hydroxyl radicals $(\mathrm{OH})$, and nitrate radicals (in the dark); and explore the changes in biological activity of DE before and after the atmospheric transformations take place (Zielinska et al., 2009).

Modern light-duty diesel engines emit relatively low amounts of volatile organic compounds (VOC) and particulate matter (DPM), while $\mathrm{NO}_{\mathrm{x}}$ emissions range from 300$500 \mathrm{ppm}$. At these high levels of $\mathrm{NO}_{\mathrm{x}}(>1 \mathrm{ppm}$ in-chamber mixing ratio for $30 \mu \mathrm{g} \mathrm{m}^{-3}$ DPM in-chamber mass concentrations), the formation of $\mathrm{OH}$ radicals and ozone will be extremely low and any $\mathrm{OH}$ or ozone produced will be rapidly removed from the system through reactions with $\mathrm{NO}$ to form $\mathrm{NO}_{2}$ and nitric acid (Finlayson-Pitts and Pitts, 2000). The photochemical transformation of organic compounds will be effectively shut down, making the photochemical experiments carried out in the sunlight not efficient or relevant to atmospheric conditions. Therefore, it was necessary to remove excess $\mathrm{NO}_{\mathrm{x}}$ by developing a $\mathrm{NO}_{\mathrm{x}}$ denuder (Zielinska et al., 2009). In addition, the modern diesel engine emits very low amounts of VOC, which resulted in typical concentrations of less than $10 \mathrm{ppb}$ of VOC in the chamber. In most urban ambient atmospheres, VOC excess due to various source emissions, such as gasoline vehicles, is chemically available (Finlayson-Pitts and Pitts, 2000; Zielinska et al., 2004a). Therefore, in some experiments additions of VOC and/or $\mathrm{OH}$ radical to the chamber atmosphere were made to enhance the reactivity of the mixture and simulate urban atmospheres.

This article focuses on the SOA production and characterization of polar organic compounds (POC) from aged DE in a series of experiments carried out at EUPHORE in 2006. A more comprehensive discussion of the project is available in Zielinska et al. (2009).

\section{Experimental system and analysis}

\subsection{EUPHORE facility and experimental design}

The EUPHORE chamber is currently one of the best equipped and largest $\left(\sim 204 \mathrm{~m}^{3}\right)$ outdoor simulation chambers in the world (Becker, 1996), which allows investigation of atmospheric transformation processes under psuedorealistic ambient conditions (dilution in the range of 1:300400). The chamber is made of a fluorine-ethene-propene (FEP) foil, with a thickness of $127 \mu \mathrm{m}$ (Du Pont). This foil transmits more than $80 \%$ of the radiation in the wavelength range of $280-640 \mathrm{~nm}$, and the surface-to-volume ratio of the chamber is $0.96 \mathrm{~m}^{-1}$ (Becker, 1996). All experiments were conduct at a relative humidity $<1 \%$.

A modern diesel engine (i.e. a common rail direct injection, turbocharged, inter-cooled engine) was obtained from Ford Motor Company in England. The $1.8 \mathrm{~L}$, Lynx V277 90PS Stage 3, Delphi Fuel System, Fixed Geometry Turbo engine is used in Ford Focus and Transit Connect automobiles. The dynamometer system is equipped with a continuous gas analyzer (Horiba), which monitors the engine-out gaseous emissions $\left(\mathrm{CO}, \mathrm{CO}_{2}, \mathrm{NO}_{\mathrm{x}}, \mathrm{THC}, \mathrm{O}_{2}\right)$. The system also records fluid temperatures, RPM, and load. The engine was operated under a load of $60 \mathrm{Nm}$, which represents approximately $50 \%$ of total engine power. A low sulfur diesel fuel (47 ppm, with $15 \%$ total aromatic content) was utilized, and steady-state conditions were achieved (30 $\mathrm{min}$ warm-up) prior to each DE injection.

Before starting each experiment the chamber was flushed for a few hours with purified air (continuous monitoring of gas and particle constituents was performed during flushing), and the DE was introduced to the chamber through a split valve system when the water and oil temperatures reached approximately 88 and $90^{\circ} \mathrm{C}$, respectively. A mixing fan $\left(4000 \mathrm{~m}^{3} \mathrm{~h}^{-1}\right)$ within the chamber was used to assure the rapid mixing of constituents. The fan was switched off after approximately 5 minutes to avoid excessive loss of particles to the chamber wall (i.e. impaction due to continued turbulence). If additional reactants were introduced to the chamber (e.g. VOCs), the fan was switched on for a short duration (1-2 min) to achieve fast mixing of the reactants.

The initial two series of experiments were carried out in January 2005 (winter campaign) and May 2005 (summer campaign), followed by a second summer campaign in MayJune 2006. The test matrix provided experiments that examine the effects of aging and $\mathrm{NO}_{3}$ radical (obtained from $\mathrm{N}_{2} \mathrm{O}_{5}$ decomposition) reactions in the dark, photo-oxidation, and $\mathrm{OH}$ radical reactions in the light on the composition of DE.

Table 1 shows the combined dark (D) and light (L) experimental matrix. All D runs were done with the chamber protective cover on, and all $\mathrm{L}$ runs with the protective cover removed. The purpose of the light exposures was to examine the effects of photolysis reactions on the exhaust composition, while the dark experiments provide a baseline dataset for modern DE aging without the influence of sunlight.

VOC concentrations in the chamber atmosphere following DE injections were typically less than $10 \mathrm{ppb}$ (confirmed by in-situ GC/MS and canister sampling followed by GC/MS analysis for 71 compounds ranging from $\mathrm{C}_{2}$ $\mathrm{C}_{11}$; see Zielinska et al., 2009). Therefore, light experiments with addition of formaldehyde (as a source of $\mathrm{OH}$ radical from the photolysis reaction), toluene as a representative VOC $\left(2190 \pm 259 \mu \mathrm{g} \mathrm{m}^{-3}\right.$; see Table 4 for specific values), or a mixture of several aromatic compounds including naphthalene, were conducted. Two different VOC mixtures were added to the chamber for three experiments in 
Table 1. Dark (D) and Light (L) Exposure Test Matrix.

\begin{tabular}{|c|c|c|}
\hline $\begin{array}{l}\text { Run Description/with } \\
\text { (Abbreviated Name) }\end{array}$ & Purpose & $\begin{array}{l}\text { \# of } \\
\text { Runs }\end{array}$ \\
\hline $\begin{array}{l}\text { Diesel Exhaust Only } \\
\text { Dark (D-1) }\end{array}$ & $\begin{array}{l}\text { Determine changes in exhaust } \\
\text { composition due to aging in chamber. }\end{array}$ & 3 \\
\hline $\begin{array}{l}\text { Diesel Exhaust }+\mathrm{N}_{2} \mathrm{O}_{5} \\
\text { Dark (D-2) } \\
\left(\mathrm{DE}+\mathrm{N}_{2} \mathrm{O}_{5}\right)\end{array}$ & $\begin{array}{l}\text { Investigate effects of } \mathrm{NO}_{3} \text { on diesel } \\
\text { exhaust composition. } \mathrm{N}_{2} \mathrm{O}_{5} \text { decomposes } \\
\text { to form } \mathrm{NO}_{2} \text { and } \mathrm{NO}_{3} \text {. }\end{array}$ & 3 \\
\hline $\begin{array}{l}\text { Diesel Exhaust Only } \\
\text { Light (L-1) }\end{array}$ & $\begin{array}{l}\text { Examine effects of photolysis reactions on } \\
\text { exhaust composition, low } \mathrm{NO}_{\mathrm{x}}\end{array}$ & 4 \\
\hline $\begin{array}{l}\text { Diesel Exhaust }+\mathrm{HCHO} \\
\text { Light }(\mathrm{L}-2) \\
(\mathrm{DE}+\mathrm{OH})\end{array}$ & $\begin{array}{l}\text { Study reactions of } \mathrm{OH} \text { radicals (from } \\
\mathrm{HCHO} \text { photolysis) with diesel exhaust } \\
\text { under low } \mathrm{NO}_{\mathrm{x}}\end{array}$ & 6 \\
\hline $\begin{array}{l}\text { Diesel Exhaust + Toluene, } \\
\text { Light }(\mathrm{L}-3) \\
(\mathrm{DE}+\mathrm{tol})\end{array}$ & $\begin{array}{l}\text { Diesel exhaust as seed aerosol during the } \\
\text { oxidation of toluene. Low } \mathrm{NO}_{\mathrm{x}} \text { conditions }\end{array}$ & 4 \\
\hline
\end{tabular}

2006 to supplement the gaseous atmospheres. The compositions of both mixtures and the resulting initial concentrations in the chamber are listed in Table S1 (Supplemental): http://www.atmos-chem-phys.net/10/609/2010/ acp-10-609-2010-supplement.pdf.

In the initial phase of these experiments (Winter 2005) it was recognized that the specific aims of this work could not be achieved without effective denudation of $\mathrm{NO}_{\mathrm{x}}\left(\mathrm{NO}+\mathrm{NO}_{2}\right)$ prior to infusion of exhaust into the reaction chamber. Therefore, a newly developed $\mathrm{NO}_{\mathrm{x}}$ denuder was used in the 2006 experiments discussed in this article (unless otherwise stated). For more information on the $\mathrm{NO}_{\mathrm{x}}$ denuder development and application see Zielinska et al. (2009) and Samy (2009).

\subsection{Sampling instrumentation and analysis}

Determination of particle size number and volume concentrations were accomplished using a Scanning Mobility Particle Sizer (SMPS) (TSI-3936). $\quad \mathrm{NO}_{\mathrm{x}}$ and $\mathrm{NO}_{\mathrm{y}}$ species were monitored using chemiluminescence (ECO Physics CLD 770AL, Teledyne API 200AU, Advanced Pollution Instrumentation, Inc., San Diego, CA) and Fourier Transfer Infrared (FTIR; NICOLET Magna 550 w/liquid $\mathrm{N}_{2}$ cooled MCT detector) instruments. The White mirror FTIR system (553.5 m optical path) monitored toluene and formaldehyde in experiments with specified additions, along with other gas phase species (glyoxal, methylglyoxal) with a spectral resolution of $1 \mathrm{~cm}^{-1}$ and a time resolution of $5 \mathrm{~min}$. See Gomez Alvarez et al. (2007) for description of FTIR-DOAS determination of glyoxal and methylglyoxal at EUPHORE. An ozone monitor (Monitor Labs ML9810) and $\mathrm{J}_{\mathrm{NO} 2}$ radiometers (for direct and reflected sunlight) were interfaced with the EUPHORE data acquisition system. The volume of the chamber was supplemented with the dry, clean air to keep the chamber at a slightly positive pressure and the dilution rate was monitored by $\mathrm{SF}_{6}$ addition to the chamber at the beginning of each experiment. Several past studies have addressed chamber specifications and systems (e.g. Koltz et al., 1998; Volkamer et al., 2001; Martin and Wirtz, 2005).

In-situ VOC measurements were periodically made with the EUPHORE GC/MS system (Varian 3400 interfaced with a MS Saturn 2000), which incorporates a cryogenic sample pre-concentration trap (SPT). The GC/MS system is located on the platform below the chamber, and is interfaced with a sampling port ( $2.5 \mathrm{~m}, 1 / 8^{\prime \prime} \mathrm{PTFE}$ sampling line). The GC was equipped with a $30 \mathrm{~m}$ DB-624 (Cyanopropenyl Polysiloxane) fused silica capillary column (J\&W Scientific, $0.32 \mathrm{~mm}$ id, $1.8 \mu \mathrm{m}$ film). A $15 \mathrm{~min}$ sample collection time with an EMF controller $(40 \mathrm{ml} / \mathrm{min}$; total sample volume $=600 \mathrm{ml})$ was used, and desorption was performed at $270^{\circ} \mathrm{C}$.

The particle-associated SVOC were collected from the chamber at the end of the exposures, using an XAD-4 (Aldrich Chemical Company, Inc.) coated annular denuder followed by a $90 \mathrm{~mm}$ Teflon-impregnated glass fiber (TIGF) filter and XAD-4 cartridge with a 100 SLPM flow (Gundel et al., 1995). The XAD-denuder strips the gas-phase species by molecular diffusion out of a laminar flow stream, before collection of the particles on the second stage (filter/cartridge) (Peters et al., 2000). DPM was collected on quartz fiber filters following each experiment and analyzed for organic and elemental carbon (OC/EC) by thermal/optical reflectance (Chow et al., 2004). Sulfate and nitrate analysis was performed by ion chromatography (Dionex, DX500). All filter/XAD samples were stored in a freezer at the EUPHORE facility and shipped to the Desert Research Institute (DRI) at 
the conclusion of the campaigns. Samples were packed in coolers with frozen blue ice and shipped using an overnight delivery service (which resulted in 2-4 days transfer time).

Prior to the campaign, TIGF filters $(90 \mathrm{~mm})$ were cleaned by sonication for $10 \mathrm{~min}$ in dichloromethane $\left(\mathrm{CH}_{2} \mathrm{Cl}_{2}\right)$ twice, with the solvent replaced and drained, and sonicated for $10 \mathrm{~min}$ in methanol twice with the solvent replaced. Amberlite XAD-4 (Aldrich Chemical Company, Inc.) was washed with liquinox soap and rinsed with hot water, followed with DI water and technical grade methanol (3-4 times). The XAD-4 was then extracted using a Dionex Accelerated Solvent Extractor (Dionex ASE 300 Accelerated Solvent Extractor) for $15 \mathrm{~min} / \mathrm{cell}$ with $\mathrm{CH}_{2} \mathrm{Cl}_{2}$ at $1500 \mathrm{psi}$ and $80^{\circ} \mathrm{C}$, followed by acetone. It was then dried in a vacuum oven at $50^{\circ} \mathrm{C}$.

The SVOCs collected on each denuder-filter-XAD sampling train were extracted separately with high-purity, HPLC grade solvents (Fisher Sci.). Filters and XAD were extracted with $\sim 170 \mathrm{~mL}$ 1:1:1 of $\mathrm{CH}_{2} \mathrm{Cl}_{2}$, hexane and methanol by accelerated solvent extraction (ASE) at DRI. The ASE method pressurizes and heats the media for $15 \mathrm{~min} / \mathrm{cell}$ at $1500 \mathrm{psi}$ and $80^{\circ} \mathrm{C}$. All media was extracted twice under the same conditions and then combined for each sample to assure completed extraction of analytes. Samples from both light and dark exposures were analyzed for a suite of SVOC, which includes POC listed in Table S2: http://www.atmos-chem-phys.net/10/609/ 2010/acp-10-609-2010-supplement.pdf, and are classified by compound groups including: alkanoic acids, alkanedioic acids, and aromatics acids. The following deuterated POC internal standards were added to the samples prior to extraction: hexanoic acid- $\mathrm{d}_{11}$, benzoic acid- $\mathrm{d}_{5}$, succinic acid- $\mathrm{d}_{4}$, adipic acid- $\mathrm{d}_{10}$, suberic acid- $\mathrm{d}_{12}$, homovanillic-2,2 acid- $\mathrm{d}_{2}$, myristic acid- $\mathrm{d}_{27}$, oleic- 9,10 acid- $\mathrm{d}_{2}$, tetradecanedioic acid- $\mathrm{d}_{24}$, eicosanoic acid- $\mathrm{d}_{39}$, cholesterol- $\mathrm{d}_{6}$. The extract underwent a trimethylsilyl (TMS) derivatization (Nolte et al., 2002; Rinehart et al., 2006), utilizing a mixture of bis-(trimethylsilyl)-trifluoracetamide (BSTFA) $+1 \%$ (wt) trimethylchorosilane (TMCS) with pyridine (silylation grade) to enhance detection sensitivity. Derivatized samples were analyzed by electron impact (EI) GC/MS at DRI. A Varian CP-3800 GC equipped with a CP-8400 Autosampler and interfaced to a Varian 4000 Ion Trap Mass Spectrometer was used to perform splitless injections onto a $30 \mathrm{~m} \mathrm{5 \%}$ phenylmethylsilicone fused silica capillary column (DB-5MS, Agilent Technologies), with an integrated $10 \mathrm{~m}$ of deactivated guard column. Calibration checks were analyzed following sample analyses. All individual compound calibration checks were within $20 \%$ (usually $<10 \%$ ). Field blanks underwent extraction and analysis in the same manner for blank subtraction.

The XAD coated glass annular denuder was extracted at the EUPHORE facility immediately following sampling, with the same solvent ratio previously described. Approximately $200 \mathrm{~mL}$ of solvent was poured into the denuder section, which had been capped at one end. The other end was capped, and the denuder was manually inverted about 30 times. The solvent was drained and the procedure repeated two more times. Extractions of field blanks were performed on-site and all extracts were concentrated to $\sim 3 \mathrm{~mL}$ by rotary evaporation. All annular denuder extracts were refrigerated during the campaign, followed by shipment (with filter/XAD samples) to DRI for analysis by GC/MS.

\subsection{Chamber wall loss correction and percent yield}

SOA mass production was determined following a sizesegregated, first-order wall-loss correction. First-order wallloss beta $(\beta)$ coefficients as defined by Fuchs (1964),

$\frac{d N\left(D_{p}, t\right)}{d t}=-\beta\left(D_{p}\right) N\left(D_{p}, t\right)$

were calculated using diesel in dark (no addition) experimental SMPS data for selected bins (14 total) throughout the size range $(17.5-1015 \mathrm{~nm})$, followed by extrapolation to determine all bin values. In this approach, the diesel in dark (no addition) experiment can be viewed as a "baseline" chamber atmosphere when evaluating SOA mass production. The size-segregated $\beta$ values ranged from $1-15 \times 10^{-5} \mathrm{~s}^{-1}$ and displayed good agreement with diameter specific values and theoretical trends discussed in previous work (Crump and Seinfeld, 1981; Park et al., 2001; Johnson et al., 2005). Particle loss for each size bin was accounted for and added to SMPS number concentrations for each 5 min time-step before conversion to total particle volume concentration assuming spherical particles. This procedure was performed for all reported experiments, and the conversion to mass assumes an aerosol density of $1 \mathrm{~g} \mathrm{~cm}^{-3}$.

Toluene (as a representative VOC) was added to the chamber atmosphere, following DE injection in four separate experiments (Sect. 3.3). SOA percent (\%) yield [SOA mass formed $\left(\mu \mathrm{g} \mathrm{m}^{-3}\right) /$ toluene mass reacted $\left(\mu \mathrm{g} \mathrm{m}^{-3}\right)$ multiplied by 100] for toluene addition experiments (L-3) was determined by monitoring toluene (FTIR, 5-min average) data for changes in mass concentrations (corrected for dilution) during aging. Glyoxal and methylglyoxal yields were determined following correction for secondary loss (photolysis [ $\mathrm{J}($ glyoxal $\left.)=\mathrm{J}\left(\mathrm{NO}_{2}\right)^{*} 0.0109\right]$ from Klotz et al., 2001; $\left[\mathrm{J}(\right.$ methylglyoxal $\left.)=\mathrm{J}\left(\mathrm{NO}_{2}\right) * 0.019\right]$ from Plum et al., 1983; and $\mathrm{OH}$-reaction $\mathrm{K}_{\mathrm{OH}}$ from Meller et al., 1991 as described in Volkamer et al., 2001). A plot of concentrations of each compound versus reacted precursor (toluene determined by FTIR) was evaluated for slope following a least-squares linear regression. The slope in this analysis was used to determine yield (Gomez Alvarez et al., 2007). 


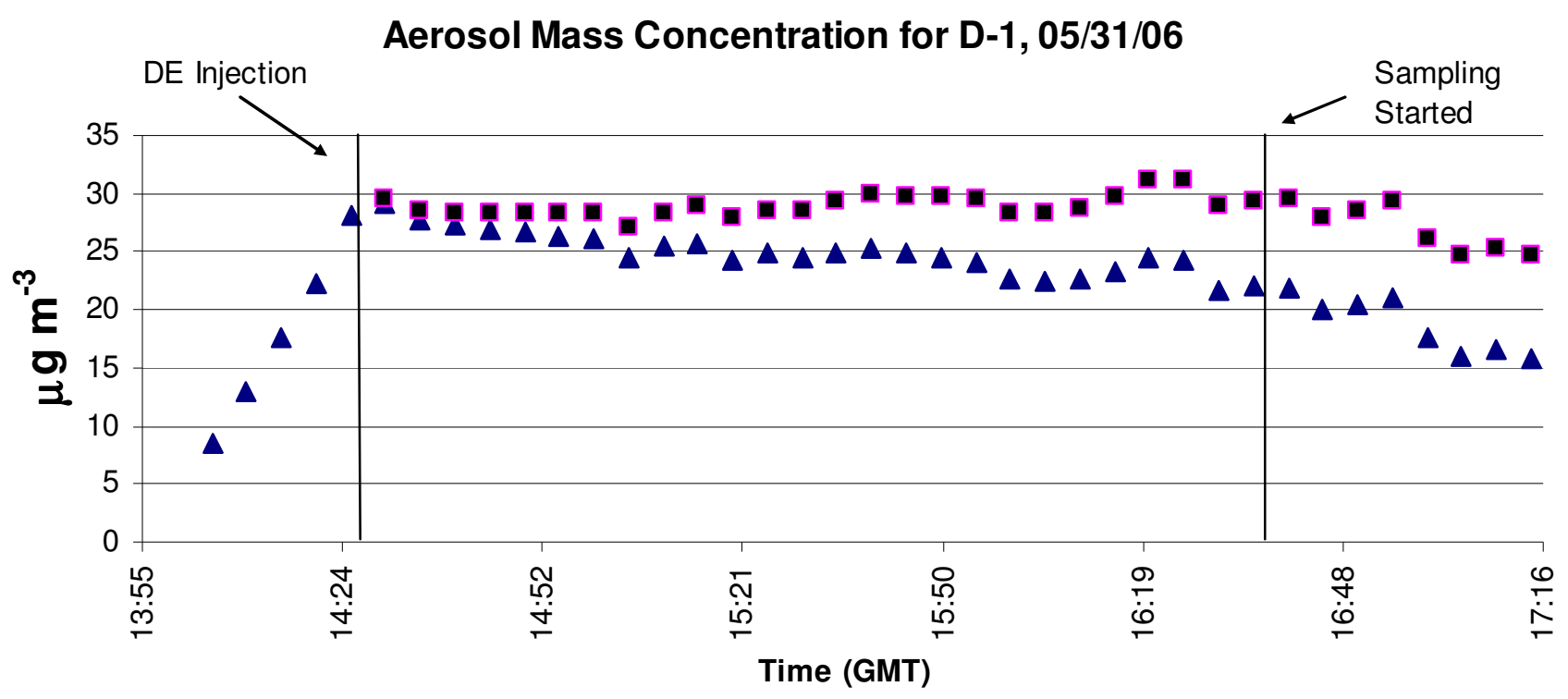

SMPS Data Collected a SMPS Data Corrected

Fig. 1. SMPS data correct for wall loss in a diesel in dark experiment, D-1 on 05-31-06.

\section{Results and discussion}

\subsection{SOA production}

Figure 1 displays a 2006 diesel in dark baseline experiment (D-1, 05/31/06) with both collected and wall loss corrected SMPS data (as discussed above). After over $2 \mathrm{~h}$ of aging, the corrected value is within $0.1 \%$ of the initial aerosol mass following injection. This indicates that the wall loss correction procedure does account for the main loss mechanism in a dark baseline experiment (values are included in Table 2). In addition, examination of corrected particle profiles at different stages of aging (e.g. $1 \mathrm{~h}$, $2 \mathrm{~h}$ ) also indicates an appropriate accounting for the main aerosol loss mechanism with profiles that appear to be uniformly conserved and centered in the accumulation mode (see Fig. S1 in supplement: http://www.atmos-chem-phys. net/10/609/2010/acp-10-609-2010-supplement.pdf).

SOA mass production values from the 2006 campaign can be viewed in Table 2. The \%SOA of the final inchamber mass concentration following aging was calculated using the mass difference (i.e. mass production) between the post-injection and pre-sampling masses corrected for wall losses. SOA \% production increased with $\mathrm{OH}$ radical (from HCHO photolysis) experiments (L-2), versus diesel in light (L-1) experiments. The greatest \% production values are from the diesel in light with toluene addition (L-3) experiments. The $\mathrm{OH}$ radical concentrations for the L-3a and L-3b (toluene addition) experiments were $5.4 \times 10^{6}$ and $3.3 \times 10^{6}$ molecules $\mathrm{cm}^{-3}$, respectively, indicating a similar in-chamber atmosphere reactivity (values calculated using rate constant from Atkinson, 1994). See the toluene addition experiment Sect. 3.3 for more discussion.

Figure 2 displays the $\mathrm{L}-2 \mathrm{~b}$ experiment ( $\mathrm{DE}+\mathrm{OH}$ radical +VOC mix, Table 2) with aerosol mass concentrations $\left(\mu \mathrm{g} \mathrm{m}^{-3}\right)$ and VOC (ppb) data through out the DE injection, aging, and the beginning of sample collection. This figure includes both non-corrected and size-resolved wall loss corrected SMPS data. Non-corrected particle profiles observed during DE aging in the L-2b experiment are provided in supplemental Fig. S2: http://www.atmos-chem-phys.net/10/ 609/2010/acp-10-609-2010-supplement.pdf. Nearly a quarter of the resulting aerosol mass (L-2b in Table 2) at the beginning of sampling is newly formed SOA. Decomposition of shorter life time VOC (o-xylene, isobutyl benzene) is observed, while less reactive VOC (benzene) displays very little decomposition for the $4.75 \mathrm{~h}$ sunlight exposure time (Finlayson-Pitts and Pitts, 2000). GC/MS analysis indicated a similar decomposition for all substituted benzene derivatives (listed in Table S1: http://www.atmos-chem-phys.net/ 10/609/2010/acp-10-609-2010-supplement.pdf), and naphthalene concentrations decreased below the detection limit prior to sample collection (see discussion below). The significant production of o-toluic acid in this experiment is notable with approximately 3 times the concentration found in the particle phase, relative to the $\mathrm{L}-2 \mathrm{a}(\mathrm{DE}+\mathrm{OH})$ experiment without VOC addition. See Sect. 3.2 for more discussion on the o-toluic acid concentrations and production pathway. 
Table 2. \%SOA of the final in-chamber mass concentration prior to sample collection. "Post-injection mass" indicates in-chamber DPM immediately following injection. "Pre-sampling mass" indicates DPM concentration following aging and has been correct for wall-loss.

\begin{tabular}{|c|c|c|c|c|c|c|}
\hline $\begin{array}{c}\text { Date } \\
\mathrm{mm} / \mathrm{dd} / \mathrm{yy}\end{array}$ & Experiment & $\begin{array}{r}\text { Aging Time } \\
{(\text { hours })^{\mathrm{a}}}^{\mathrm{a}}\end{array}$ & $\begin{array}{l}\text { Post-injection } \\
\text { mass }\left(\mu \mathrm{g} \mathrm{m}^{-3}\right)\end{array}$ & $\begin{array}{r}\text { Pre-sampling } \\
\text { mass }\left(\mu \mathrm{g} \mathrm{m}^{-3}\right)\end{array}$ & $\begin{array}{r}\text { Mass Difference } \\
\qquad\left(\mu \mathrm{g} \mathrm{m}^{-3}\right)\end{array}$ & $\begin{array}{r}\% \text { SOA of } \\
\text { Final Mass }\end{array}$ \\
\hline $05 / 31 / 06$ & $\begin{array}{l}\text { D-1, Diesel in Dark } \\
\text { (baseline) }\end{array}$ & 2.08 & 29.5 & 29.4 & -0.1 & 0.0 \\
\hline 06/08/06 & L-1a, Diesel in Light & 4.42 & 44.1 & 41.7 & -2.4 & 0.0 \\
\hline $06 / 02 / 06$ & $\begin{array}{l}\text { L-1b, Diesel in Light } \\
\text { with VOC mix\#2 }\end{array}$ & 4.75 & 49.5 & 46.1 & -3.4 & 0.0 \\
\hline 06/01/06 & $\begin{array}{l}\text { D-2, Diesel in dark } \\
\text { w/ } \mathrm{N}_{2} \mathrm{O}_{5}+\mathrm{VOC} \text { mix\#1 }\end{array}$ & 2.90 & 28.8 & 29.7 & 0.9 & 3.0 \\
\hline 06/05/06 & $\begin{array}{l}\text { L-2a, Diesel in Light } \\
\text { with НСНО }\end{array}$ & 4.83 & 40.7 & 44.8 & 4.1 & 9.2 \\
\hline 06/07/06 & $\begin{array}{l}\text { L-2b, Diesel in Light } \\
\text { with } \mathrm{HCHO}+\mathrm{VOC} \text { mix\#2 }\end{array}$ & 4.75 & 29.3 & 38.8 & 9.5 & 24.5 \\
\hline 06/06/06 & $\begin{array}{l}\text { L-3a, Diesel in Light } \\
\text { with Toluene }\left(1990 \mu^{-3} \mathrm{~m}^{-3}\right)\end{array}$ & 3.92 & 32.9 & 55.6 & 22.7 & 40.8 \\
\hline 06/09/06 & $\begin{array}{l}\text { L-3b, Diesel in Light } \\
\text { with Toluene }\left(1960 \mathrm{\mu g} \mathrm{m}^{-3}\right)\end{array}$ & 4.27 & 40.7 & 73.8 & 33.1 & 44.9 \\
\hline
\end{tabular}

a Aging time is defined as the time elapsed between DE injection and initiation of sampling. DE injections in all light (L) experiments were initiated between 10:00-12:00 to allow for mid-day solar exposure conditions.

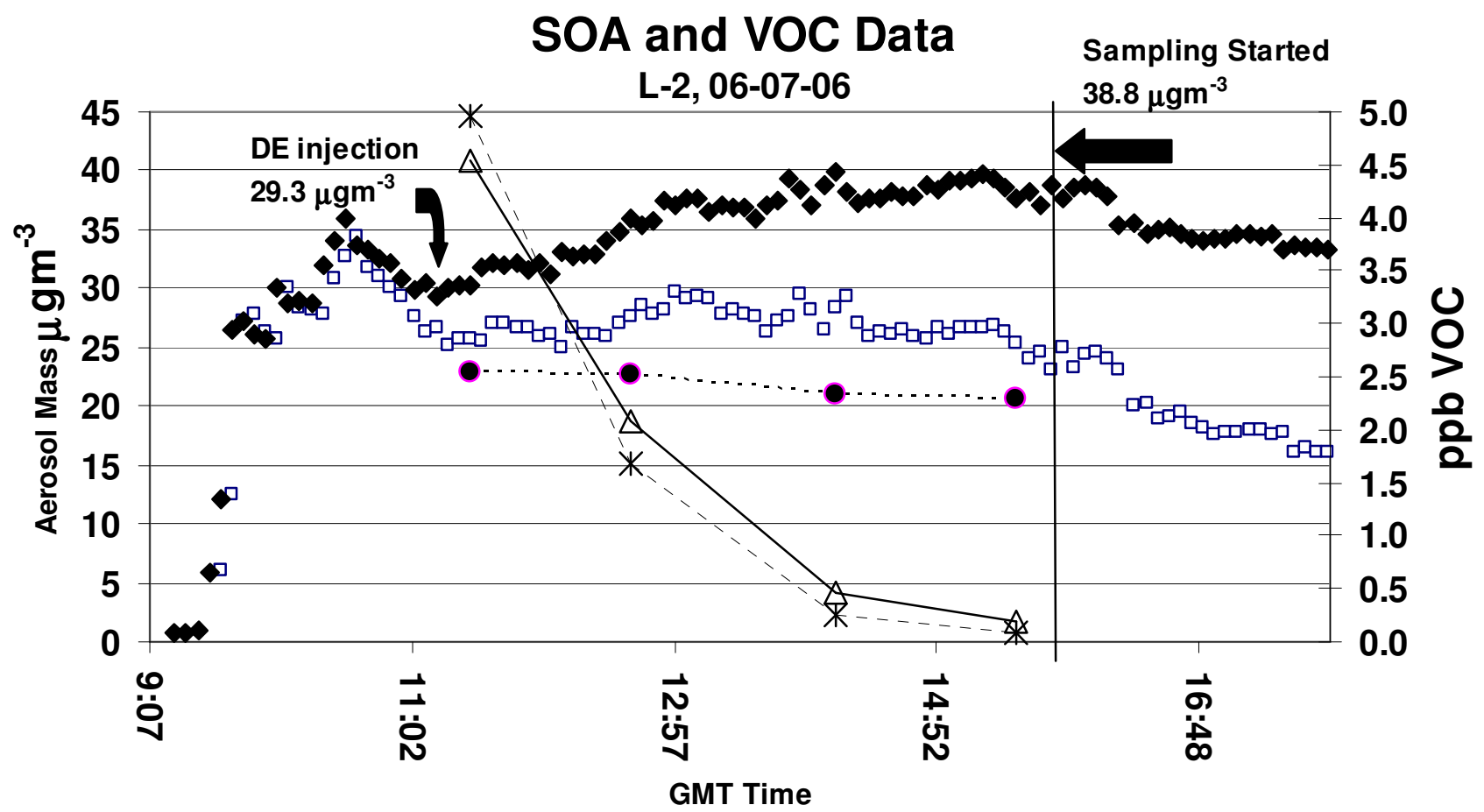

SMPS non-corrected

SMPS corrected

- benzene $\triangle$ o-xylene - - - - - isobuthyl benzene

Fig. 2. L-2b (OH) , 06/07/06 SOA (left y-axis) and VOC (right y-axis) data. 


\section{OC/EC Ratio}

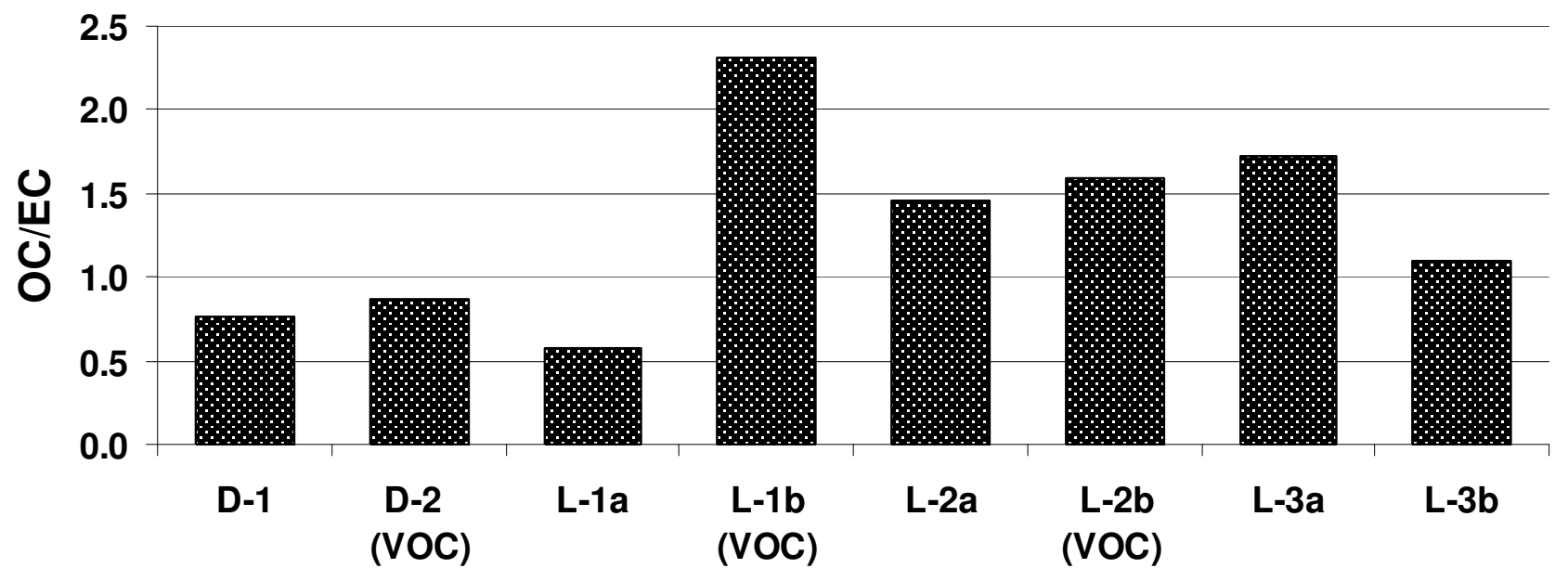

Fig. 3. OC/EC ratio for 2006 EUPHORE experiments.

The addition of VOC in the L-2b (DE+OH+VOC) experiment did significantly increase the SOA \% production, relative to the $\mathrm{L}-2 \mathrm{a}(\mathrm{DE}+\mathrm{OH})$ experiment without VOC addition (06/05/06). Assuming complete reaction of VOC in Table S1: http://www.atmos-chem-phys.net/10/609/ 2010/acp-10-609-2010-supplement.pdf (excluding benzene, GC/MS data indicated concentrations of VOC at or near detection limit following aging), a $2.3 \%$ yield relative to consumed VOC was determined for the L-2b experiment, which corresponds to the "low yield aromatics" yield values presented and discussed by Odum et al. (1997). A similar trend in SOA \% production was observed in the 2005 summer campaign and values can be viewed in the supplemental Table S3: http://www.atmos-chem-phys.net/10/609/ 2010/acp-10-609-2010-supplement.pdf. Due to changes in the $\mathrm{NO}_{\mathrm{x}}$ denuder technology, and several other factors (discussed in supplemental: http://www.atmos-chem-phys. net/10/609/2010/acp-10-609-2010-supplement.pdf) a direct comparison of the 2005 to 2006 data was not made here (Zielinska et al., 2009).

Following each chamber experiment, DPM were collected on quartz fiber filters and analyzed for OC/EC by thermal/optical reflectance method (see Sect. 2.2). The OC/EC ratios for 2006 EUPHORE experiments are shown in Fig. 3. With the exception of the L-1a (DE only) experiment, all light exposures exhibit an increase in OC/EC relative to dark experiments. The L-1a atmosphere was not photochemically active (as discussed above) due to the very low concentrations of VOC. Several experiments exhibit a percent increase in OC/EC (relative to dark experiments) that exceeds $100 \%$ (L-1b, L-2b, L-3a), with the L-1b experiment displaying the highest increase at $204 \%$. The L-3 (toluene addition) and VOC addition experiment in sunlight L-1b, show significant contribution of pyrolized organic carbon, which indicates the presences of highly polar and/or oligomeric organic compounds formed as SOA (Chow et al., 2004). See Zielinska et al. (2009) for more detail on OC/EC, and pyrolized organic carbon results.

These high increases of OC/EC ratio are not always consistent with the lack of mass production calculated using the SMPS method discussed above. For example, the L-1b (DE+VOC) experiment displays a significant increase of OC/EC while no mass production is observed (Table 2).There may be several reasons explaining these apparent inconsistencies: (1) positive quartz filter artifact (i.e. adsorption of VOC on the quartz filter) which would result in artificially high OC contents; (2) uncertainties of OC/EC measurements (Chow et al., 2004), amplified by a very low mass of particles collected on quartz filters (Zielinska et al., 2009); and (3) assumption of spheroid particles for SMPS data. If fresh emissions evolve from initially non-spherical to more spherical particles during the SOA production process, then the SMPS method of mass determination would potentially include an associated uncertainty of measurement.

In contrast to recent work (Weitkamp et al., 2007; Robinson et al., 2007), the modern DE and the experimental setup used at EUPHORE suggests that no significant SOA production results from aging of $\mathrm{DE}$ in sunlight without addition of an exogenous radical source (HCHO) and/or addition of VOC (including toluene addition experiments). For example, the L-1a experiment (DE in light with no additions) actually exihibits a lower OC/EC value relative to D-1 (DE in dark). Several factors may explain the difference between the EUPHORE and the Weitkamp et al. (2007) results. A few of these include the use of a single-cylinder $4.5 \mathrm{~kW}$ generator for a DE source by Weitkamp et al; differences in 
Table 3. Gas and particle phase concentrations $\left(\mu \mathrm{g} \mathrm{mg}^{-1} \mathrm{EC}\right)$ for selected organic acids.

\begin{tabular}{|c|c|c|c|c|c|c|c|c|}
\hline particle phase compounds & D-1 & $\begin{array}{r}\mathrm{D}-2 \\
(\mathrm{VOC}) \\
\left(\mathrm{N}_{2} \mathrm{O}_{5}\right)\end{array}$ & L-1a & $\begin{array}{r}\mathrm{L}-1 \mathrm{~b} \\
(\mathrm{VOC})\end{array}$ & $\begin{array}{l}\mathrm{L}-2 \mathrm{a} \\
(\mathrm{OH})\end{array}$ & $\begin{array}{r}\mathrm{L}-2 \mathrm{~b} \\
(\mathrm{OH}) \\
(\mathrm{VOC})\end{array}$ & $\begin{array}{r}\mathrm{L}-3 \mathrm{a} \\
(\mathrm{TOL})\end{array}$ & $\begin{array}{r}\text { L-3b } \\
(\mathrm{TOL})\end{array}$ \\
\hline heptanoic acid $\left(\mathrm{C}_{7}^{\mathrm{a}}\right)$ & 100 & 58 & 49 & 634 & 201 & 708 & 6537 & 1684 \\
\hline nonanoic acid $\left(\mathrm{C}_{9}\right)^{\mathrm{b}}$ & 274 & 546 & 36 & 278 & 207 & 161 & 453 & 84 \\
\hline Oleic acid $\left(\mathrm{C}_{18}\right)$ & 198 & 150 & $\mathrm{ND}^{\mathrm{c}}$ & 87 & 161 & 4 & 147 & 91 \\
\hline maleic acid $\left(\mathrm{d}-\mathrm{C}_{4}\right)$ & ND & ND & ND & 2189 & 542 & 367 & 16408 & 6663 \\
\hline Succinic acid $\left(\mathrm{d}-\mathrm{C}_{4}\right)$ & 154 & 300 & 181 & 1541 & 1349 & 180 & 600 & 464 \\
\hline methylsuccinic acid $\left(\mathrm{d}-\mathrm{C}_{5}\right)$ & 24 & 52 & 23 & 330 & 184 & 208 & 188 & 105 \\
\hline glutaric acid $\left(\mathrm{d}-\mathrm{C}_{5}\right)$ & ND & ND & ND & 9 & 26 & 76 & ND & ND \\
\hline suberic acid $\left(\mathrm{d}-\mathrm{C}_{8}\right)$ & ND & ND & ND & 3 & ND & 3 & ND & ND \\
\hline Sebacic acid $\left(\mathrm{d}-\mathrm{C}_{10}\right)$ & ND & ND & ND & 7 & ND & ND & 27 & 27 \\
\hline 1,11-undecanedicarboxylic acid $\left(\mathrm{d}-\mathrm{C}_{13}\right)$ & ND & ND & ND & 6 & ND & ND & ND & ND \\
\hline 1,12-dodecanedicarboxylic acid $\left(\mathrm{d}-\mathrm{C}_{14}\right)$ & ND & 10 & ND & 9 & ND & ND & ND & 4 \\
\hline 3,4-dimethylbenzoic acid & 0 & 1235 & 4 & 1685 & 65 & 69 & 46 & 6 \\
\hline dimethylbenzoic acid isomers ${ }^{\mathrm{d}}$ (sum) & 3239 & 2781 & 553 & 2023 & ND & 644 & 17 & 1346 \\
\hline o-toluic acid & 10 & 13 & 9 & 312 & 5 & 15 & 5 & 6 \\
\hline m-toluic acid & 12 & 21 & 5 & 23 & 12 & 6 & 8 & 5 \\
\hline p-toluic acid & 16 & 28 & 10 & 169 & 23 & 23 & 12 & 10 \\
\hline phthalic acid & ND & 492 & 166 & 743 & 285 & 630 & 324 & 257 \\
\hline phenylacetic acid & ND & ND & ND & 13 & ND & 26 & ND & ND \\
\hline \multicolumn{9}{|l|}{ gas phase compounds } \\
\hline 3,4-dimethylbenzoic acid & ND & 71 & ND & 154 & ND & 14 & ND & ND \\
\hline dimethylbenzoic acid isomers (sum) & 30 & 2016 & 9 & 2360 & 136 & 186 & 147 & 16 \\
\hline o-toluic acid & 27 & 35 & 6 & 657 & 79 & 98 & 73 & 5 \\
\hline m-toluic acid & 13 & 52 & 2 & 86 & 36 & 16 & 31 & 3 \\
\hline p-toluic acid & 89 & 267 & 18 & 913 & 288 & 201 & 238 & 20 \\
\hline
\end{tabular}

a "C\#" indicates carbon number, while "d" signifies whether the compound is a diacid.

$\mathrm{b}$ Both particle and gas phases included as sum for nonanoic acid.

c ND, not detected.

${ }^{\mathrm{d}}$ Isomers include: 2,6-; 2,5-; 2,4-; 3,5-; 3,4-dimethylbenzoic acid.

$\mathrm{NO}_{\mathrm{x}}$ concentrations (Weitkamp et al., 2007, did not monitor $\mathrm{NO}_{\mathrm{x}}$, but define conditions as "high $\mathrm{NO}_{\mathrm{x}}$ ") and chamber volume/light source (Weitkamp et al., 2007, use a $10 \mathrm{~m}^{3}$ Teflon bag with artificial lighting). These substantial experimental differences and lack of extensive chemical speciation data in previous work make direct comparisons between these two sets of experiments impossible.

\subsection{POC concentrations}

The analysis for a limited number of POC (54 listed in Table S2: http://www.atmos-chem-phys.net/10/609/2010/ acp-10-609-2010-supplement.pdf) was conducted to assess the composition of modern DE and the formation of photochemical transformation products. Understanding the relationship between SOA production and changes in POC composition in light versus dark chamber experiments may help to delineate the compound specific contribution to overall SOA mass production. Gas and particle phase concentrations of selected POC are shown in Table 3. Note that all organic compound concentrations are expressed in relation to elemental carbon (i.e. microgram of species per milligram of EC). The inherent assumption in this normalization procedure is that EC mass will remain unchanged while atmospheric transformations of speciated organic compounds take place within the chamber atmosphere. Supplemental Tables S4-S7: http://www.atmos-chem-phys.net/10/609/2010/ acp-10-609-2010-supplement.pdf include all measured POC concentrations.

Gas phase POC concentrations are generally more dominated by alkanoic and aromatic acids, while particle phase alkanedioic (diacids) values are relatively higher (Figs. 4 5 ), as would be expected from partitioning theory (Pankow, 1994; Seinfeld and Pandis; 1998). The L-3 (DE+tol) experiments display the greatest diacids production (particle phase) relative to the dark experiments (D-1, D-2), followed by the L-2 (DE+OH) experiments (with or without VOC). The significant difference between the L-3 experiments may 


\section{Gas-Phase POC}

\section{Alkanoic acids $\boxminus$ Aromatic acids $⿴$ Alkanedioic acids}

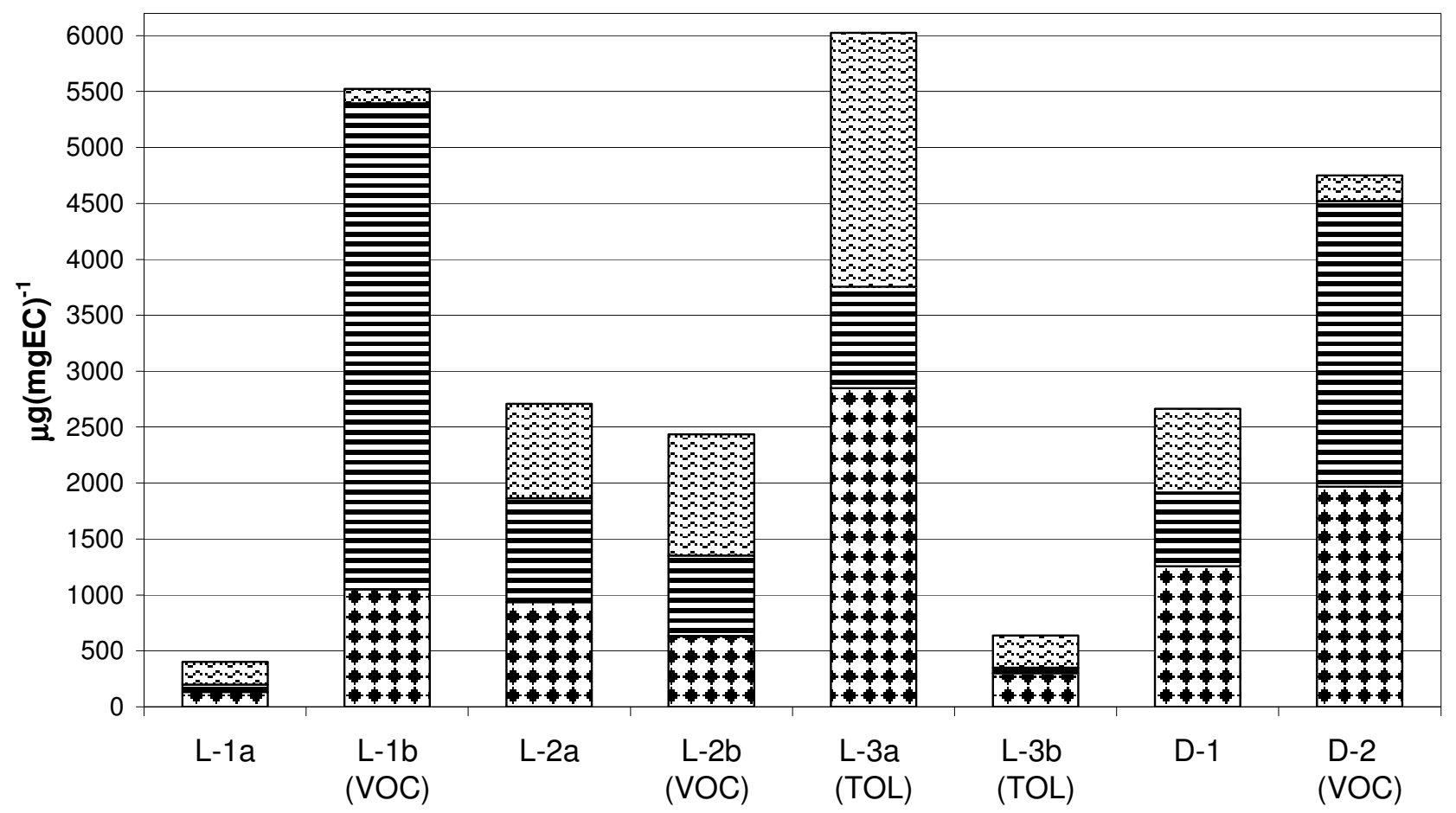

Fig. 4. Gas-phase POC concentrations for three compound classes.

be due to the reduced solar radiation input, due to overcast conditions on 06/09/06 (see Sect. 3.3 for further discussion).

A closer look at the light L-1a (DE) and L-1b (DE+VOC) experiments in Figs. 4 and 5, reveals the significant changes to the overall POC concentrations and profile resulting from the addition of VOC. While other experimental conditions are similar (e.g. post-injection mass, aging time) and the two experiments exhibit no significant SOA production, the changes in chemical composition do suggest a significant chemical transformation has taken place in both gas and particle phases. The L-2a (DE+OH) and L-2b (DE+OH+VOC) experiments do not display such drastic changes in measured total POC concentrations, but do exhibit a significant difference in SOA production (Table 2). Although post-injection mass is lower in the L-2b experiment, leading to a reduced total aerosol surface area (i.e. particle size profiles are similar), the \% SOA production is over 2.6 times greater than the L-2a experiment. However, only targeted POC were quantified for these exposures by the derivitization followed by GC/MS analysis method. This technique does not include analysis for multifunctional, highly oxygenated and/or nitrogenated, oligomeric compounds that may have been produced in the L-2a and L-2b experiments and may explain the differences in the observed \% SOA production (Zielinska et al., 2009). Further discussion of POC composition is provided in the supplemental: http://www.atmos-chem-phys. net/10/609/2010/acp-10-609-2010-supplement.pdf.

Figure 6 displays the particle phase concentrations ( $\mu \mathrm{g} \mathrm{mg}^{-1} \mathrm{EC}$ ) of 1,2-benzenedicarboxylic acid (phthalic acid) and phenylacetic acid (only detected in L-1b, L-2b w/VOC experiments). These two compounds were not detected in the dark baseline (D-1) experiments, and the highest concentrations are associated with experiments that included VOC (w/naphthalene) additions (D-2, L-2b, L-1b). Phthalic acid has been shown to be the only major product from the photolysis of naphthalene on $\mathrm{SiO}_{2}$ and $\mathrm{Al}_{2} \mathrm{O}_{3}$ surfaces in air (Barbas et al., 1993), and more recent chamber experiments have identified phthalic anhydride and phthaldialdehyde as a transformation product of the $\mathrm{OH}$ radical initiated reactions of naphthalene (Wang et al., 2007).

Phthalic acid has been proposed as an indicator for photochemical SOA formation, and as a surrogate for SOA contribution to ambient samples in past studies (Fine et al., 2004; Fraser et al., 2003). However, the determination of \% SOA from a single compound may produce significant errors in estimations as is evident from Table 2. For example, the L$1 \mathrm{~b}$ (DE+VOC) experiment displays the highest relative phthalic acid concentration but does not show any significant 


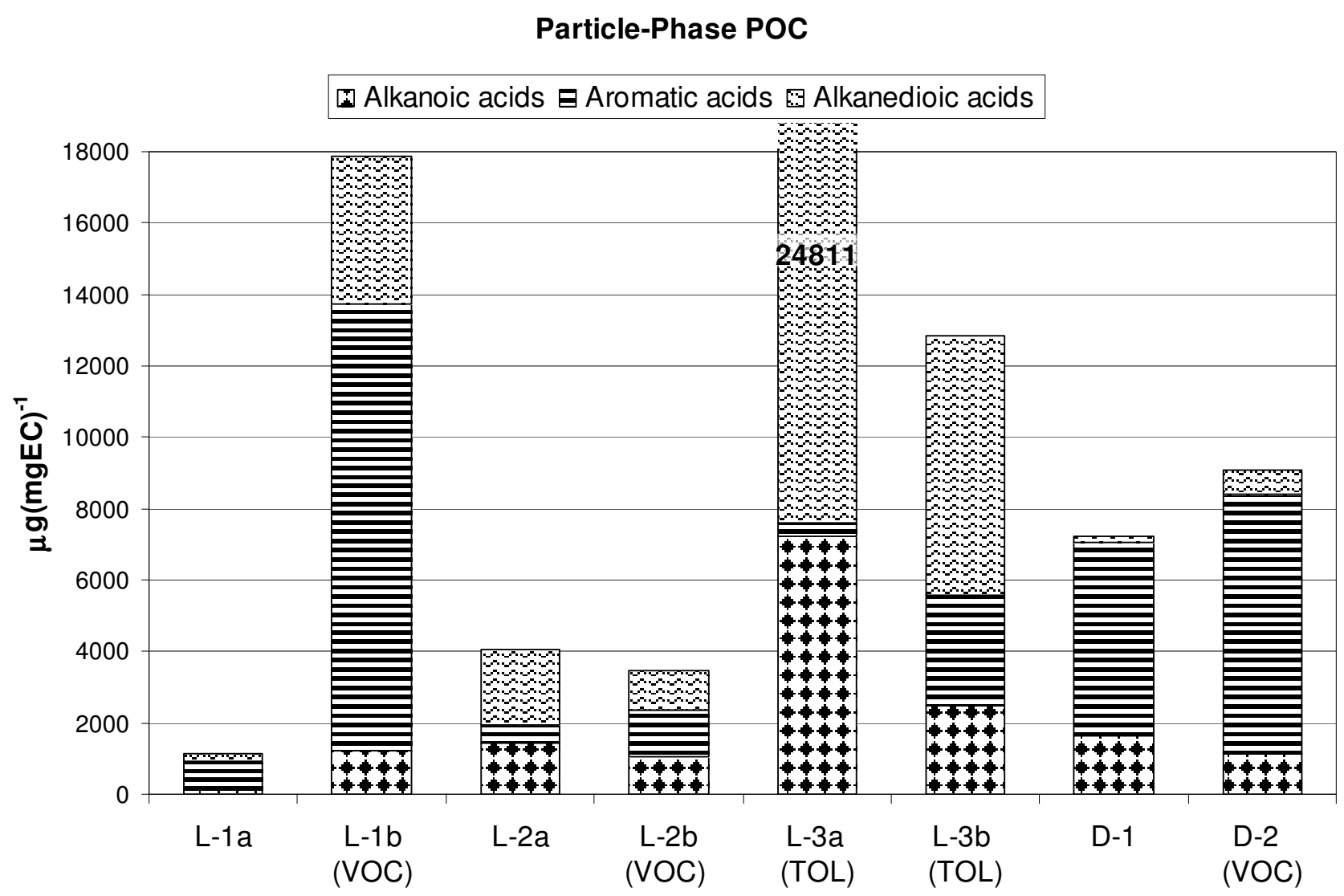

Fig. 5. Particle-phase POC concentrations for three compound classes.

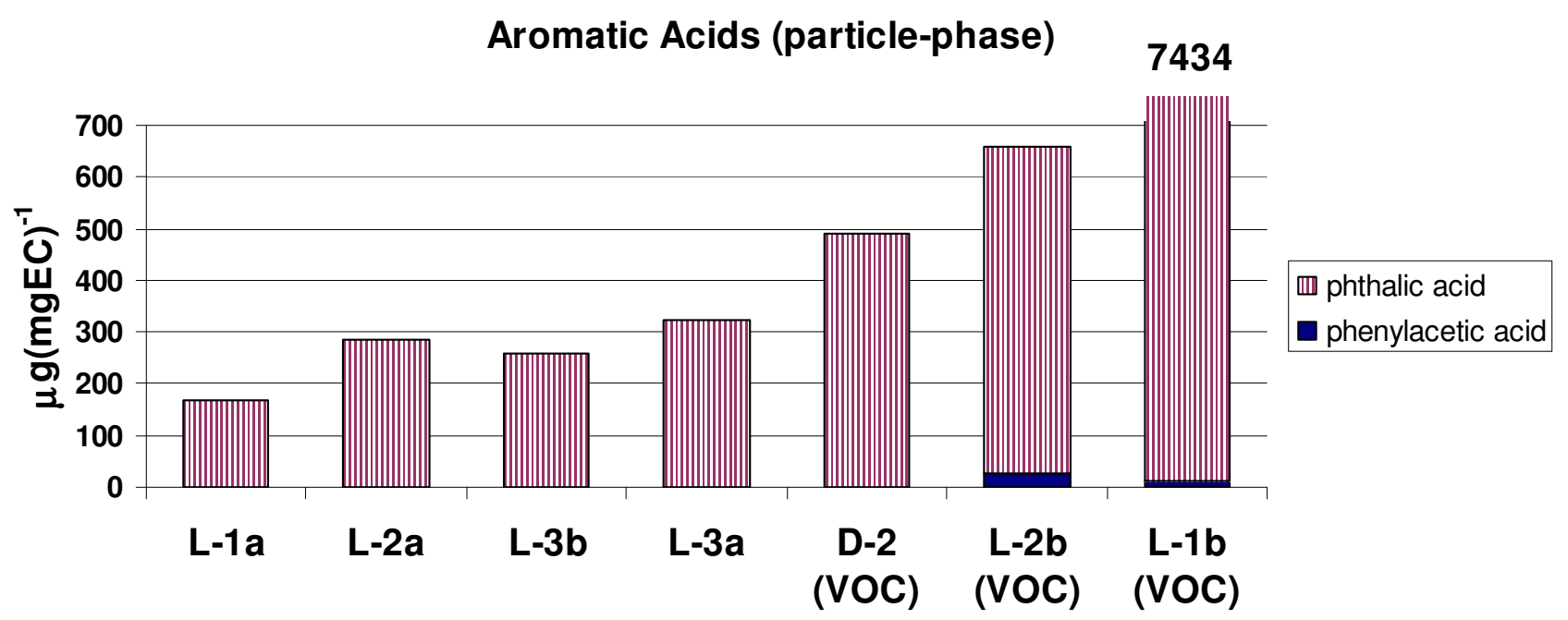

Fig. 6. Concentrations of phthalic and phenylacetic acids in particle-phase.

SOA production. Possible precursors of phthalic acid are discussed in the supplemental: http://www.atmos-chem-phys. net/10/609/2010/acp-10-609-2010-supplement.pdf.
The D-2 $\left(\mathrm{NO}_{3}\right.$ radicals from $\mathrm{N}_{2} \mathrm{O}_{5}$ decomposition) experiment provides an example of relatively high phthalic acid production in the absence of light. $\mathrm{NO}_{3}$ radicals are very reactive and are observed during late evening and nighttime hours in the atmosphere, followed by rapid removal via 
photolysis and reaction with $\mathrm{NO}$ during the day. $\mathrm{NO}_{3}$ radical reactions with naphthalene proceed by initial addition to the aromatic rings to form nitrooxycyclohexadienyl-type radicals, which can react with $\mathrm{O}_{2}$ or $\mathrm{NO}_{2}$ to yield various products (Pitts et al., 1985; Atkinson et al., 1987; Sasaki et al., 1997). While the ring retaining reaction pathways, which result in the formation of nitronaphthalenes and hydroxynitronaphthalenes represents the major product formation yields (Atkinson and Arey, 2007), the ring cleavage pathways may contribute to the production of carboxylic aromatic acids.

Decomposition followed by oxidation of the substituted $\left(\geq C_{2}\right)$ benzene derivatives and/or PAH, is the likely production pathway for the observed phenylacetic acid. For example, the ethylbenzene-OH pathway proposed by Forstner et al. (1997) is a possible production route for phenylacetic acid in the L-2b (DE+OH+VOC) and L-1b (DE+VOC) experiments. A change in chamber atmosphere reactivity due to VOC addition is apparent, with the L-2b having the maximum ozone production of all experiments (251 ppb), followed by the L-1b experiment (188 ppb) (see Table S8: http://www.atmos-chem-phys.net/10/609/2010/ acp-10-609-2010-supplement.pdf for all values). This may have promoted the production of a more complex set of transformation products.

Table 3 displays the toluic acid isomer concentrations in both gas and particle phases. Dominated by gas phase production and observed at the highest levels in VOC mix\#2 addition experiments (L-1b, L-2b), o-toluic acid is likely to be the second generation oxidation product of o-xylene, which initially forms o-tolualdehyde at significant yields following hydrogen abstraction from one of the methyl groups (Atkinson et al., 1991). Further oxidation of o-tolualdehyde results in the formation of otoluic acid (Forstner et al., 1997). The supplemental information includes all POC concentrations in both gas (Tables S4 and S5: http://www.atmos-chem-phys.net/10/609/ 2010/acp-10-609-2010-supplement.pdf) and particle (Tables S6 and S7: http://www.atmos-chem-phys.net/10/609/ 2010/acp-10-609-2010-supplement.pdf) phases.

The 5 dimethylbenzoic acid isomers $(2,6-; 2,5-; 2,4-$ ; 3,5-; 3,4-dimethylbenzoic acid) analyzed in this study are presented as a sum value in both gas and particle phases in Table 3 . The highest gas phase concentrations are in experiments with VOC addition (L-1b $>$ D$2>\mathrm{L}-2 \mathrm{~b}$ ), indicating a gas phase transformation of $1,2,4$ trimethylbenzene, which was included in the VOC mix (Table S1: http://www.atmos-chem-phys.net/10/609/2010/ acp-10-609-2010-supplement.pdf) and monitored for decomposition by GC/MS. Further confirmation of this production pathway was achieved by delineation of isomers that are likely products from oxidation of 1,2,4trimethylbenzene methyl groups (2,5-; 3,4-dimethylbenzoic acid), versus isomers with prohibitive structures (2,6-; 2,4-; 3,5-dimethylbenzoic acid). Figure 7 provides a closer look at the 3,4-dimethylbenzoic acid concentrations in both gas and particle phases. This isomer was not detected in the D1 (dark baseline) experiment, and was only present in the VOC addition experiments in the particle phase. The relatively high corresponding gas phase concentration in these experiments suggests a gas phase oxidation leading to saturation and partitioning (Pankow, 1994).

Several dicarboxylic acids listed in Table 3, including: succinic, methylsuccinic, glutaric, suberic, and sebacic were identified as major components in atmospheric PM during photochemical smog episodes (Grosjean et al., 1978). Succinic acid has been shown to be present at relatively high concentrations in many global urban sites (Ho et al., 2006 and references therein). Possible precursors (in DE) suggested in a past study (Hatakeyama et al., 1987) include cyclopentene for glutaric or succinic acids, and 3-methylcyclopentene for methylsuccinic. However, the modern DE used in this study had very low concentrations of these potential precursors, and the contribution from other precursors (e.g. aromatic compounds) can not be ruled out.

To evaluate whether diacids are relatively more abundant than monoacids in the light exposure experiments, a ratio of the quantified (Table S2: http://www.atmos-chem-phys.net/ 10/609/2010/acp-10-609-2010-supplement.pdf) alkanedioic to alkanoic acids is shown in Fig. 8. Even though our analytical method determined the concentrations of a limited number of compounds, it is apparent that both the gas and particle phases display a higher ratio for the light versus dark experiments. The high particle phase ratio in the L-1b (DE+VOC) experiment can be explained in part by the relatively high $\mathrm{C}_{4}$ and $\mathrm{C}_{5}$ diacids production (Table 3), which may be the result of a combination of factors including: higher actinic flux during $\mathrm{L}-1 \mathrm{~b}\left(\mathrm{~J}\left(\mathrm{NO}_{2}\right)=8.7 \pm 0.7 \times 10^{-3}\right)$ versus $\mathrm{L}-1 \mathrm{a}$ $\left(\mathrm{J}\left(\mathrm{NO}_{2}\right)=6.4 \pm 1.2 \times 10^{-3}\right)$, addition of VOC in L-1b resulting in a more reactive mixture with increased concentrations of possible precursors and a greater ozone concentration (190 ppb maximum in L-1b versus $20 \mathrm{ppb}$ in L-1a), and the highest post-injection mass concentration $\left(49.4 \mu \mathrm{g} \mathrm{m}^{-3}\right.$; Table 2) leading to increased particle phase partitioning (Donahue et al., 2006).

\subsection{Toluene addition experiments}

To determine if SOA production (\% yield) from toluene in the presence of a complex mixture (modern DE), is significantly different from SOA \% yield in simplified experimental mixtures (Johnson et al., 2004), the four L3 (DE+tol) experiments were further evaluated. Table 4 displays the $\%$ yield $\left[\left(\operatorname{SOA}\left(\mu \mathrm{g} \mathrm{m}^{-3}\right) / \Delta \operatorname{tol}\left(\mu \mathrm{g} \mathrm{m}^{-3}\right)\right) \times 100\right]$ for all L-3 experiments, with the initial toluene concentration $\left([\mathrm{tol}]_{\mathrm{o}}\right)$ and $[\mathrm{tol}]_{\mathrm{o}} /\left[\mathrm{NO}_{\mathrm{x}}\right]_{\mathrm{o}}$ ratio. Generally, the $\%$ yield values (average $=5.3 \pm 1.6$ ) are within the range of "low- $\mathrm{NO}_{\mathrm{x}}$ " $\left([\mathrm{tol}]_{\mathrm{o}} /\left[\mathrm{NO}_{\mathrm{x}}\right]_{\mathrm{o}}\right.$ range 10.9-17.8) experiments conducted by Johnson et al. (2004) and Hurley et al. (2001). However, these experiments were conducted without seed aerosol and the increase in yield with decreasing $[\text { tol }]_{\mathrm{o}} /\left[\mathrm{NO}_{\mathrm{x}}\right]_{\mathrm{o}}$ ratio 


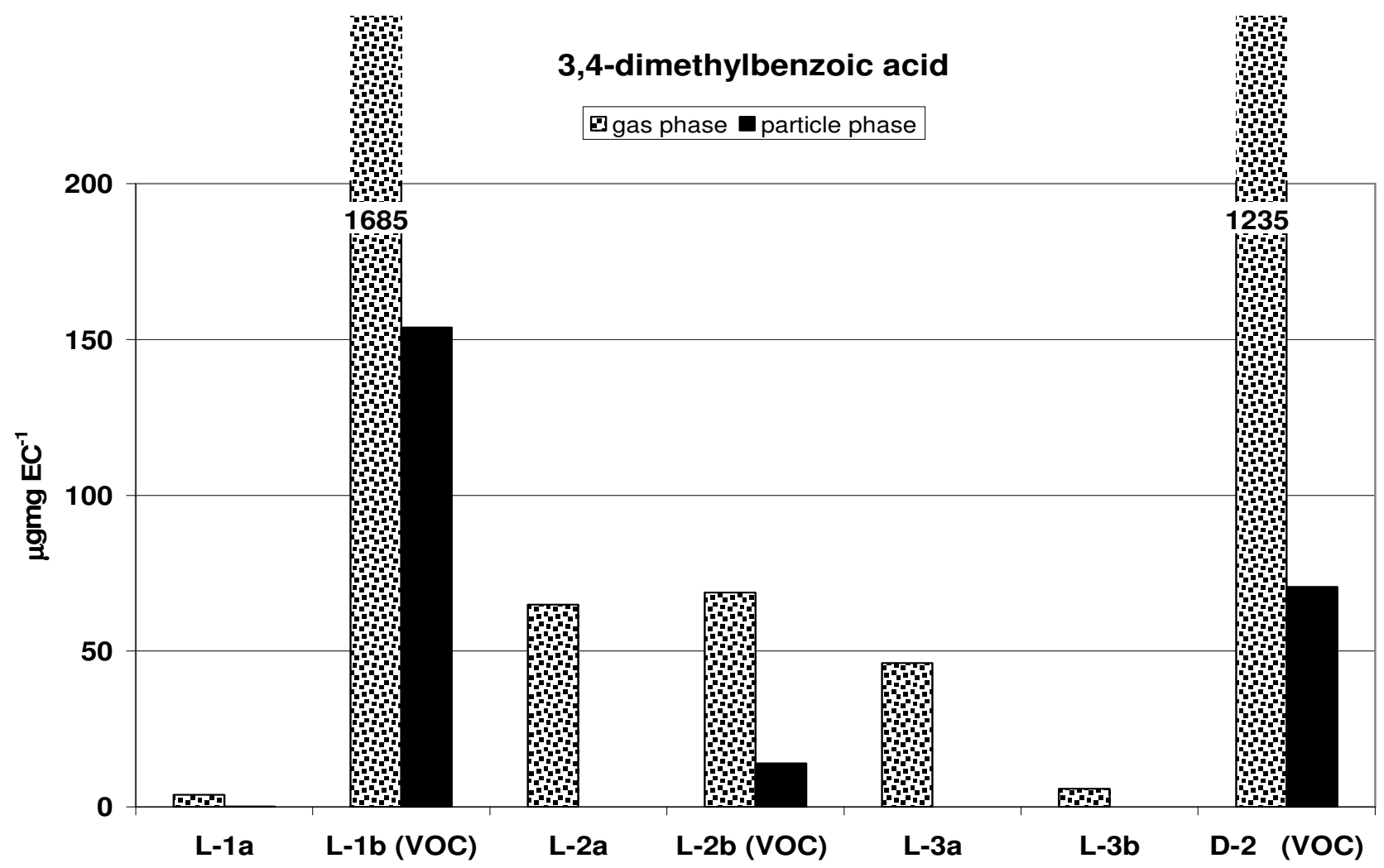

Fig. 7. Concentration of 3,4-dimethylbenzoic acid.

Alkanedioic to Alkanoic Acids Ratio

Gas-Phase $\square$ Particle-Phase

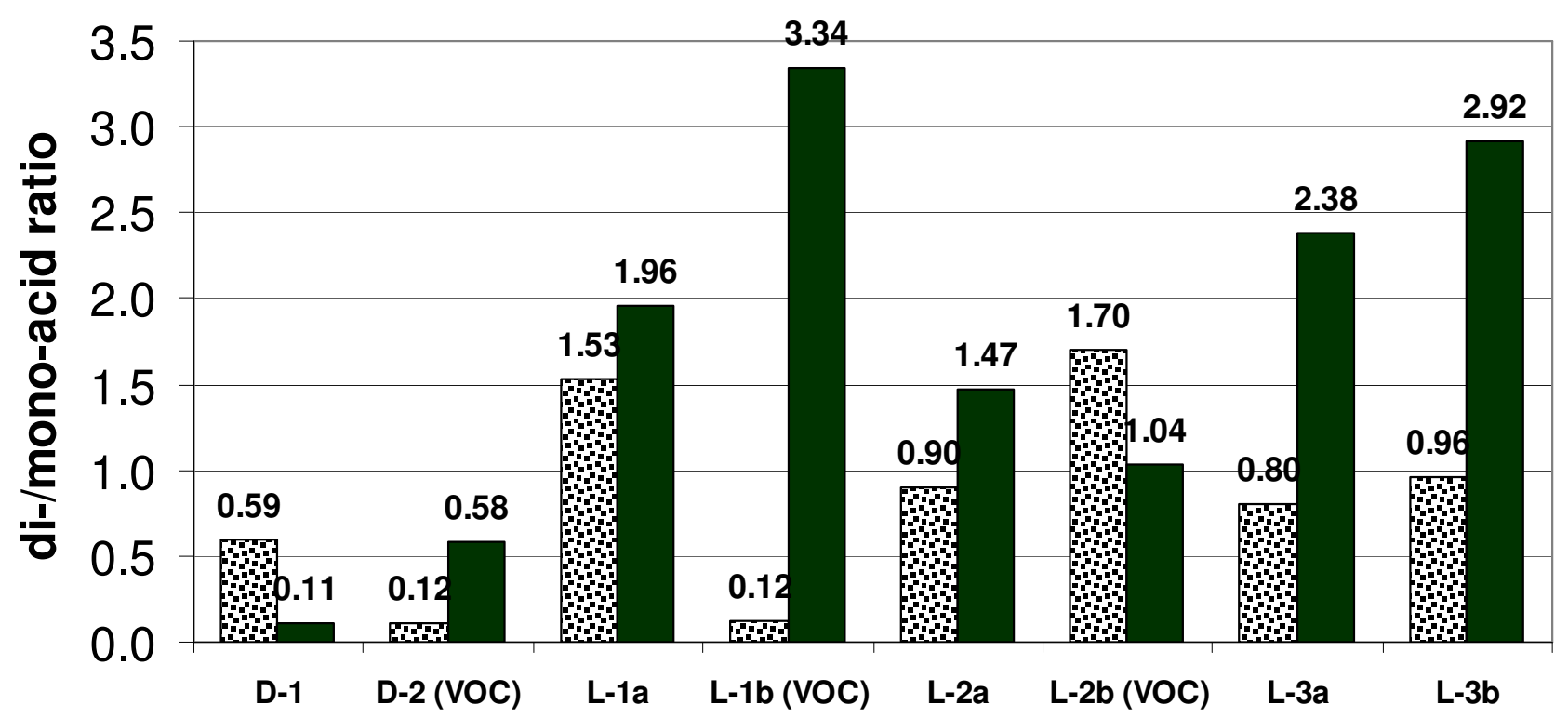

Fig. 8. Ratio of alkanedioic to alkanoic acids for 2006 diesel aging experiments. 
Table 4. L-3, toluene addition experiments conducted at EUPHORE.

\begin{tabular}{|c|c|c|c|c|c|c|c|c|c|c|}
\hline $\begin{array}{l}\text { Name, } \\
\text { Date }\end{array}$ & $\begin{array}{l}{[\mathrm{tol}]_{\mathrm{o}}} \\
(\mathrm{ppb})\end{array}$ & $\begin{array}{r}{[\mathrm{tol}]_{\mathrm{o}} /} \\
{\left[\mathrm{NO}_{\mathrm{x}}\right]_{\mathrm{o}}} \\
\text { ratio }\end{array}$ & $\begin{array}{c}\text { aging } \\
\text { time } \\
\text { (hours) }^{\text {a }}\end{array}$ & $\begin{array}{c}\mathrm{J}\left(\mathrm{NO}_{2}\right) \\
\left(\mathrm{s}^{-1}\right) \\
\times 10^{-3}\end{array}$ & $\begin{array}{c}{[\text { tol] }} \\
\text { reacted } \\
(\mathrm{ppb})\end{array}$ & $\begin{array}{c}{[\mathrm{OH}]^{\mathrm{b}}} \\
\left(\mathrm{molec} \mathrm{cm}^{-3}\right) \\
\times 10^{6}\end{array}$ & $\begin{array}{c}\text { ozone }^{\mathrm{c}} \\
(\mathrm{ppb})\end{array}$ & $\begin{array}{c}\% \text { yield }^{\mathrm{d}} \\
(\mathrm{SOA})\end{array}$ & $\begin{array}{c}\% \text { yield }^{\mathrm{e}} \\
(\text { glyoxal) }\end{array}$ & $\begin{array}{l}\% \text { yield }^{f} \\
\text { (methyl- } \\
\text { glyoxal) }\end{array}$ \\
\hline $\begin{array}{l}\mathrm{L}-3 \mathrm{a}, \\
06 / 06 / 06\end{array}$ & 528 & 19.2 & 3.62 & $8.3 \pm 0.7$ & 213 & 5.37 & 112 & $3.3 \pm 0.7$ & $17.0 \pm 5.1$ & $11.6 \pm 3.5$ \\
\hline $\begin{array}{l}\text { L-3b, } \\
06 / 09 / 06\end{array}$ & 520 & 5.0 & 4.90 & $4.1 \pm 1.5$ & 132 & 3.32 & 185 & $6.8 \pm 1.4$ & $37.6 \pm 11.3$ & $37.7 \pm 11.3$ \\
\hline $\begin{array}{l}\mathrm{L}-3 \mathrm{c} \\
05 / 19 / 05\end{array}$ & 616 & 4.3 & 5.02 & $8.7 \pm 0.7$ & 272 & 4.96 & 287 & $6.4 \pm 1.3$ & $22.1 \pm 6.6$ & $\mathrm{na}^{\mathrm{g}}$ \\
\hline $\begin{array}{l}\mathrm{L}-3 \mathrm{~d}, \\
05 / 20 / 05\end{array}$ & 661 & 6.3 & 4.15 & $8.8 \pm 0.9$ & 406 & 8.34 & 251 & $4.9 \pm 1.0$ & $21.9 \pm 6.6$ & na \\
\hline
\end{tabular}

a Aging time is the total time DE aged following chamber injection and prior to beginning of sample collection.

$\mathrm{b}$ Decay of toluene was used to estimate the concentration of $\mathrm{OH}$ radicals using rate constant from Atkinson (1994).

${ }^{\mathrm{c}}$ Maximum ozone production during aging.

d $\%$ yield (relative to toluene) calculated following size-resolved wall-loss correction, assuming a $20 \%$ analytical error.

e corrected for photolysis loss using Koltz et al. (2001); correct for OH loss using Meller et al. (1991); 30\% error applied see Volkamer et al. (2005) for detailed discussion on potential sources of error.

f $30 \%$ Error applied.

g Data not available.

observed in our experiments is in more agreement with trends observed by Odum et al. (1997), which included seed aerosol and a more complex mixture of VOC.

SOA formation from a variety of precursors has been shown to be significantly impacted by $\mathrm{NO}_{\mathrm{x}}$ concentrations (Song et al., 2005; Kroll et al., 2006; Pathak et al., 2007) possibly due to the formation of different condensable products under different $\mathrm{NO}_{\mathrm{x}}$ conditions. Johnson et al. (2004) displayed the need to increase model species-independent partitioning coefficient scaling factors as $\mathrm{NO}_{\mathrm{x}}$ concentrations increased in past toluene photooxidation studies at EUPHORE, indicating a systematic impact on the SOA production process due to changes in the $[\text { tol }]_{\mathrm{o}} /\left[\mathrm{NO}_{\mathrm{x}}\right]_{\mathrm{o}}$ ratio. Since most atmospheric oxidation reactions of organics produce alkyl radicals, multifunctional organic nitrates may also be produced at significant concentrations as observed by Lim and Ziemann (2005) and Forstner et al. (1997).

Although our yield values are generally lower than those reported by Odum, our highest yield experiments, L-3b $(6.8 \pm 1.4)$ and L-3c (6.4 \pm 1.3$)$, are in good agreement with values (within $20 \%$ analytical error) for the highest $[\text { tol }]_{\mathrm{o}} /\left[\mathrm{NO}_{\mathrm{x}}\right]_{\mathrm{o}}$ (5.47) experiment conducted by Odum and coworkers on $07 / 10 / 96$ (yield $=7.4 \%$ ). It is important to note that Odum did enhance the reactivity of their mixtures by adding propene (i.e. production of radicals), and this may explain the generally higher yield trend. Upon further evaluation, Odum et al. (1997) classify toluene (along with other single substituted methyl/ethyl benzene derivatives) as a "high-yield aromatic" and using a two-product model (Pankow, 1994), produce yield curves where the amount of aerosol produced $\left(\Delta \mathrm{M}_{\mathrm{o}}\right)$ is in the range of our experiments $\left(22.7-64.1 \mu \mathrm{g} \mathrm{m}^{-3}\right)$. Our observed \% yields $(3.3 \pm 0.7$ to $6.8 \pm 1.4$ ) fall within the proposed range of 4-7\% (Odum et al., 1997), and are in agreement with more recently reported observations (Stroud et al., 2004).

Formation of glyoxal (CHOCHO) in our L-3 experiments was observed, and the $\%$ yield (relative to reacted toluene) is reported in Table 4. Glyoxal has been identified as a major primary product from the $\mathrm{OH}$-initiated oxidation of toluene (Volkamer et al., 2001), and more recent work at EUPHORE has further confirmed the dicarbonyl route proposed by Darnall et al. (1979) (see: Atkinson et al., 1980 and Gomez Alvarez et al., 2007). Our observations of nearly immediate (with 5 min time resolution) glyoxal formation following toluene addition, supports the proposed ring-cleavage pathways involving the bicycloalkyl radical (Volkamer et al., 2001), and the L-3b experiment \% yield (37.6) is in agreement with values reported recently $(37 \pm 2)$ by Gomez Alvarez et al. (2007). The significantly lower actinic flux (approximately $1 / 2$ ) in the L-3b experiment may explain the higher yield. Glyoxal loss due to photolysis is addressed in Volkamer et al. (2005), and the reassessment of \% yields from previous work (Volkamer et al., 2001) resulted in a reported value of $30.6 \pm 6 \%$ (previously $39 \pm 10.2 \%$ ), which is in agreement (within error) with our higher yield toluene addition experiments (L-3b, L-3c, L-3d). The J(glyoxal) used for loss correction in these experiments ranged from $4.5-9.6 \times 10^{-5}(\mathrm{~s}-1)$, and are typical values for natural sunlight at mid-latitude locations (Volkamer et al., 2005). Interestingly, the lowest \% yield (L-3a) experiment was also the experiment with the lowest SOA yield, and the highest $[\text { tol }]_{\mathrm{o}} /\left[\mathrm{NO}_{\mathrm{x}}\right]_{\mathrm{o}}$ ratio (19.2), which indicates that an inhibition 
of the dicarbonylic route in this system plays a role in SOA production efficiency (Gomez Alvarez et al., 2007). Formation of glyoxal oligomer species in relation to SOA formation processes has been discussed in previous studies (Kalberer et al., 2004; Hastings et al., 2005). While some correlation between glyoxal and SOA yield is observed here $\left(R^{2}=0.61\right)$, more experimentation with atmospherically relevant mixtures is needed to sufficiently parameterize these processes.

Methylglyoxal yields are included in Table 4 for the 2006 experiments. The significant production observed in the L$3 \mathrm{~b}$ experiment is similar to \% yield values recently reported (37 \pm 2 ) (Gomez Alvarez et al., 2007). When combined with the glyoxal yield, a significant fraction of the reacted toluene can be account for $(\mathrm{L}-3 \mathrm{a}=28 \%, \mathrm{~L}-3 \mathrm{~b}=75 \%)$. Formation of formaldehyde (HCHO) from decomposition of more complex organic compounds can be the result of reactions involving multi-generational products (Finlayson-Pitts and Pitts, 2000). In this study $\mathrm{HCHO} \%$ yields relative to decomposed toluene (following correction for photolysis and $\mathrm{OH}$ radical loss) ranged from 18-23\%, and showed no significant variability between the four L-3 experiments (assuming a $30 \%$ error). HCHO can originate from multiple precursors, for example, from the photolysis of glyoxal or methylglyoxal (Koch and Moortgat, 1998). Therefore, HCHO yield values reported here should be seen as a reaction system characteristic and not as an indication of a specific production pathway. The low actinic flux experiment (L-3b) did result in the lowest yield value (18\%), and observed formic acid production generally coincided with $\mathrm{HCHO}$ production (Fig. S3: http://www.atmos-chem-phys.net/10/609/ 2010/acp-10-609-2010-supplement.pdf).

\section{Conclusions}

Atmospheric transformations of emissions from a modern light-duty diesel engine equipped with oxidation catalyst have been studied in the EUPHORE outdoor simulation chamber in Valencia, Spain. It was observed that SOA production in sunlight experiments was negligible unless VOC or $\mathrm{OH}$ radicals were added to the chamber to enhance the reactivity of the mixtures. Maximal SOA production (in the range of $40 \%$ ) was observed when toluene was added to the chamber in relatively high concentrations $(400-500 \mathrm{ppb})$.

Despite the relatively low yield of SOA, significant changes were observed in the concentrations of quantified polar organic compounds (POC) at the end of each 4-6h experiment. In particular, aromatic and aliphatic diacid concentrations were enhanced in light as compared with dark exposures. Phthalic acid, a postulated photooxidation product of naphthalene, showed significant increases in concentration when naphthalene was added to the chamber as one of the VOC mixture components. Yet a significant correlation between SOA production and phthalic acid concentrations was not observed in this study. Our data suggests that addition of VOC, including naphthalene, results in a relatively higher concentration of potential SOA tracers in a complex mixture (DE). However, the lack of correlation between \%SOA and single compound concentrations (e.g. phthalic acid) suggests that more extensive chemical characterization data near sources and following aging/transport need to be considered for more accurate estimations in the ambient atmosphere.

The toluene addition experiments show consistency with previously conducted toluene oxidation studies at EUPHORE (Johnson et al., 2004; Gomez Alvarez et al., 2007) and with trends observed by Odum et al. (1997). As suggested by earlier work (Volkamer et al., 2001), a significant fraction of the reacted toluene can be accounted for when glyoxal and methylglyoxal yields are considered. The observed yield correlation between SOA, glyoxal, and other decomposition products (such as HCHO) of more complex organic compounds, suggests that reactions involving multigenerational products were occurring within the chamber atmospheres.

Acknowledgements. The financial support for this study was provided by the Health Effect Institute (HEI). We would like to thank Monica Vazquez, Esther Borras Garcia, Amalia Munoz and other staff at EUPHORE. Anna Cunningham and the Organic Analytical Laboratory (OAL) staff at DRI are thanked for all of their efforts.

Edited by: M. Petters

\section{References}

Arey, J.: Atmospheric reactions of PAHs including formation of nitroarenes, in: The Handbook of Environmental Chemistry, Vol. 3, Part I, PAHs and Related Compounds, edited by: Neilson, A. H., Springer-Verlag, Berlin/Heidelberg, Germany, 347385, 1998.

Atkinson, R.: Gas-phase tropospheric chemistry of organic compounds. J. Phys. Chem. Ref. Data, 2, 1-216, 1994.

Atkinson, R., Carter, W. P. L., Darnall, K. R., Winer, A. M., and Pitts Jr., J. N.: A smog-chamber and modelling study of the gas phase $\mathrm{NO}_{\mathrm{x}}$-air photooxidation of toluene and the cresols, Int. J. Chem. Kinet., 12, 779-834, 1980,

Atkinson, R., Arey, J., Zielinska, B., and Aschmann, S. M.: Kinetics and products of the gas-phase reactions of $\mathrm{OH}$ radicals and $\mathrm{N}_{2} \mathrm{O}_{5}$ with naphthalene and biphenyl, Environ. Sci. Technol., 21, 1014-1022, 1987.

Atkinson, R., Aschmann, S. M., and Arey, J.: Formation of ringretaining products from the $\mathrm{OH}$ radical-initiated reactions of $\mathrm{o}-$, m-, and p-xylene, Int. J. Chem. Kinet., 23, 77-97, 1991.

Atkinson, R. and Arey, J.: Atmospheric chemistry of gas-phase polycyclic aromatic hydrocarbons: Formation of atmospheric mutagens, Environ. Health Persp., 102, 117-126, 1994.

Atkinson, R. and Arey, J.: Mechanisms of the gas-phase reactions of aromatic hydrocarbons and $\mathrm{PAHs}$ with $\mathrm{OH}$ and $\mathrm{NO}_{3}$ radicals, Polycyclic Aromatic Compounds, 27, 15-40, 2007.

Barbas, J. T., Sigman, M. E., Buchanan III, A. C., and Chevis, E. A.: Photolysis of substituted naphthalenes on $\mathrm{SiO}_{2}$ and $\mathrm{Al}_{2} \mathrm{O}_{3}$, Photochem. Photobiol., 58, 155-158, 1993. 
Barsanti, K. C. and Pankow, J. F.: Thermodynamics of the formation of atmospheric organic particulate matter by accretion reactions-Part 3: carboxylic and dicarboxylic acids, Atmos. Environ., 40, 6676-6686, 2006.

Becker, K. H.: Design and Technical Development of the European Photoreactor and First Experimental Results, Final Report "EUPHORE" of the EC-Project, European Commission Contract: EV5V-CT92-0059, Brussels, Belgium, 1996.

Carey, F. A. and Sundberg, R. J.: Advanced organic chemistry, 3rd edition, Plenum Press, New York, 1990.

Chow, J. C., Watson, J. G., Chen, L. W. A., Arnott, W. P., Moosmuller, H., and Fung, K.: Equivalence of Elemental Carbon by Thermal/optical Reflectance and Transmittance with Different Temperature Protocol, Environ. Sci. Technol., 38, 4414-4422, 2004.

Crump, J. G. and Seinfeld, J. H.: Turbulent deposition and gravitational sedimentation of an aerosol in a vessel of arbitrary shape, J. Aerosol Sci., 12, 405-415, 1981.

Darnall, K. R., Atkinson, R., and Pitts, J. N.: Observation of biacetyl from the reaction of $\mathrm{OH}$ radicals with o-xylene, Evidence for ring cleavage, J. Phys. Chem., 83, 1943-1946, 1979.

Donahue, N. M., Robinson, A. L., Stainer, C. O., and Pandis, S. N.: Coupled partitioning, dilution, and chemical aging of semivolatile organics, Environ. Sci. Technol., 40, 2635-2643, 2006.

Fine, P., Chakrabarti, B., Krudysz, M., Schauer, J. J., and Sioutas, C.: Diurnal variations of individual organic compound constituents of ultrafine and accumulation mode particulate matter in the Los Angeles Basin, Environ. Sci. Technol., 38, 1296-1304, 2004.

Finlayson-Pitts, B. J. and Pitts Jr., J. N.: Chemistry of the upper and lower atmosphere, Academic Press, San Diego, CA, 2000.

Forstner, H. J. L., Flagan, R. C., and Seinfeld, J. H.: Secondary organic aerosol from the photooxidation of aromatic hydrocarbons: molecular composition, Environ. Sci. Technol., 31, 1345-1358, 1997.

Fraser, M. P., Cass, G. R., and Simoneit, B. R. T.: Air quality model evaluation data for organics, 6. C3-C24 organic acids, Environ. Sci. Technol., 37, 446-453, 2003.

Fuchs, N. A.: The Mechanics of Aerosols, Pergamon Press, New York, 1964.

Gomez Alvarez, E. G., Viidanoja, J., Munoz, A., Wirtz, K., and Hjorth, J.: Experimental confirmation of the dicarbonyl route in the photo-oxidation of toluene and benzene, Environ. Sci. Technol., 41, 8362-8369, 2007.

Graber, E. R. and Rudich, Y.: Atmospheric HULIS: How humiclike are they? A comprehensive and critical review, Atmos. Chem. Phys., 6, 729-753, 2006, http://www.atmos-chem-phys.net/6/729/2006/.

Griffin, R. J., Cocker III, D. R., and Seinfeld, J. H.: Estimate of global atmospheric organic aerosol from oxidation of biogenic hydrocarbons, Geophys. Res. Lett., 26, 2721-2724, 1999.

Grosjean, D., Van Cauwenberghe, K., Schmid, J. P., Kelley, P. E., and Pitts Jr., J. N.: Identification of C3-C10 aliphatic dicarboxylic acids in airborne particulate matter, Environ. Sci. Technol., 12, 313-317, 1978.

Gundel, L. A., Lee, V. C., Mahanama, K. R. R., Stevens, R. K., and Daisey, J. M.: Direct determination of the phase distributions of semi-volatile polycyclic aromatic hydrocarbons using annular denuders, Atmos. Environ., 29, 1719-1733, 1995.

Hamilton, J. F., Webb, P. J., Lewis, A. C., and Martín, M.: Quantifying small molecules in secondary organic aerosol formed during the photo-oxidation of toluene with hydroxyl radicals, Atmos. Environ., 39, 7263-7275, 2005.

Hatakeyama, S., Ohno, M., Weng, J., Takagi, H., and Akimoto, H.: Mechanism for the formation of gaseous and particulate products from ozone-cycloalkene reactions in air, Environ. Sci. Technol., 21, 52-57, 1987.

Hastings, W. P., Koehler, C. A., Bailey, E. L., and DeHann, D. O.: Secondary organic aerosol formation by glyoxal hydration and oligomer formation: humidity effects and equilibrium shifts during analysis, Environ. Sci. Technol., 39, 8728-8735, 2005.

Ho, K. F., Lee, S. C., Cao, J. J., Kawamura, K., Watanabe, T., Cheng, Y., and Chow, J. C.: Dicarboxylic acids, ketocarboxylic acids and dicarbonyls in the urban area of Hong Kong, Atmos. Environ., 40, 3030-3040, 2006.

Hurley, M. D., Sokolov, O., Wallington, T. J., Takekawa, H., Karasawa, M., Klotz, B., Barnes, I., and Becker, K. H.: Organic aerosol formation during the atmospheric degradation of toluene, Environ. Sci. Technol., 35, 1358-1366, 2001.

Jang, M. and McDow, S. R.: Products of Benz[a]anthracene photodegradation in the presence of known organic constituents of atmospheric aerosols, Environ. Sci. Technol., 31, 1046-1053, 1997.

Jang, M., Czoschke, N. M., Lee, S., and Kamens, R. M.: Heterogeneous atmospheric aerosol production by acid-catalyzed particlephase reactions, Science, 298, 814-817, 2002.

Johnson, D., Jenkin, M. E., Wirtz, K., and Martín, M.: Simulating the formation of secondary organic aerosol from the photooxidation of Toluene, Environ. Chem., 1, 150-165, 2004.

Johnson, D., Jenkin, M. E., Wirtz, K., Martín, M.: Simulating the Formation of Secondary Organic Aerosol from the Photooxidation of Aromatic Hydrocarbons, Environ. Chem., 2, 35-48, 2005.

Kalberer, M., Paulsen, D., Sax, M., Steinbacher, M., Dommen, J., Prevot, A. S. H., Fisseha, R., Weingartner, E., Frankevich, V., Zenobi, R., and Baltensperger, U.: Identification of polymers as major components of atmospheric organic aerosols, Science, 303, 1659-1662, 2004.

Kamens, R. M., Jeffries, H. E., Gery, M. W., Wiener, R. W., Sexton, K. G., and Howe, G. B.: The impact of $\alpha$-pinene on urban smog formation: an outdoor smog chamber study, Atmos. Environ., 15, 969-981, 1981.

Kamens, R. M., Gery, M. W., Jeffries, H. E., Jackson, M., and Cole, E. I.: Ozone-isoprene reactions: product formation and aerosol potential, Int. J. Chem. Kinet., 14, 955-975, 1982.

Kawamura, K. and Gagosian, R. B.: Implications of $\omega$ oxocarboxylic acids in the remote marine atmosphere for photooxidation of unsaturated fatty acids, Nature, 325, 330-332, 1987.

Kleindienst, T. E., Corse, E. W., Mclver, C. D., Conver, T. S., Edney, E. O., Driscoll, D. J., Speer, R. E., Weathers, W. S., and Tejada, S. B.: Secondary aerosol formation from the irradiation of simulated automobile exhaust, J. Air Waste Mange., 52, 259-272, 2002.

Kleindienst, T. E., Conver, T. S., McIver, C. D., and Edney, E. O.: Determination of secondary organic aerosol products from the photooxidation of toluene and their implications in ambient $\mathrm{PM}_{2.5}$, J. Atmos. Chem., 47, 79-100, 2004.

Klotz, B., Sorensen, S., Barnes, I., Becker, K. H., Etzkorn, T., 
Volkamer, R., Platt, U., Wirtz, K., and Martin-Reviejo, M.: Atmospheric oxidation of toluene in a large-volume outdoor photoreactor: In situ determination of ring-retaining product yields, J. Phys.Chem. A, 102, 10289-10299, 1998.

Klotz, B., Graedler, F., Sorenson, S., Barnes, I., and Becker, K. H.: A kinetic study of the atmospheric photolysis of $\alpha$-dicarbonyls, Int. J. Chem. Kinet., 33, 9-20, 2001.

Koch, S. and Moortgat, G. K.: Photochemistry of methylgloxal in the vapor phase, J. Phys. Chem., 102, 9142-9153, 1998.

Kroll, J. H., Ng, N. L., Murphy, S. M., Flagan, R. C., and Seinfeld, J. H.: Secondary organic aerosol formation from isoprene photooxidation, Environ. Sci. Technol., 40, 1869-1877, 2006.

Kroll, J. H. and Seinfeld, J. H.: Chemistry of secondary organic aerosol: Formation and evolution of low-volatility organics in the atmosphere, Atmos. Environ., 42, 3593-3624, 2008.

Lee, S., Jang, M., and Kamens, R. M.: SOA formation from the photooxidation of a-pinene in the presence of freshly emitted diesel soot exhaust, Atmos. Environ., 38, 2597-2605, 2004.

Lim, Y. B. and Ziemann, P. J.: Products and mechanism of secondary organic aerosol formation from reactions of $n$-alkanes with $\mathrm{OH}$ radicals in the presence of $\mathrm{NO}_{\mathrm{x}}$, Environ. Sci. Technol., 39, 9229-9236, 2005.

Martín, M. and Wirtz, K.: Is Benzene a precursor for secondary organic aerosol?, Environ. Sci. Technol., 39, 1045-1054, 2005.

Meller, R., Raber, W., Crowley, J. N., Jenkin, M. E., and Moortgat, G. K.: The UV-visible absorption spectrum of methylglyoxal, J. Photoch. Photobio., 62, 163-171, 1991.

Nolte, C. G., Schauer, J. J., Cass, G. R., and Simoneit, B. R. T.: Trimethylsilyl derivatives of organic compounds in source samples and in atmospheric fine particulate matter, Environ. Sci. Technol., 36, 4273-4281, 2002.

Odum, J. R., Jungkamp, T. P. W., Griffin, R. J., Forstner, H. J. L., Flagan, R. C., and Seinfeld, J. H.: Aromatics, reformulated gasoline, and atmospheric organic aerosol formation, Environ. Sci. Technol., 31, 1890-1897, 1997.

Pandis, S. N., Paulson, S. E., Seinfeld, J. H., and Flagan, C. F.: Aerosol formation in the photooxidation of isoprene and $\beta$ pinene, Atmos. Environ., 25A, 997-1008, 1991.

Pankow, J. F.: An absorption model of the gas/particle partitioning of organic compounds in the atmosphere, Atmos. Environ., 28, 185-188, 1994.

Pathak, R. K., Presto, A. A., Lane, T. E., Stanier, C. O., Donahue, N. M., and Pandis, S. N.: Ozonolysis of $\alpha$-pinene: parameterization of secondary organic aerosol mass fraction, Atmos. Chem. Phys., 7, 3811-3821, 2007, http://www.atmos-chem-phys.net/7/3811/2007/.

Park, S. H., Kim, H. O., Han, Y. T., Kwon, S. B., and Lee, K. W.: Wall loss rate of polydispersed aerosols, Aerosol Sci. Tech., 35, 710-717, 2001.

Peters, A. J., Lane, D. A., Gundel, L. A., Northcott, G. L., and Jones, K. C.: A comparison of high volume and diffusion denuder samplers for measuring semivolatile organic compounds in the atmosphere, Environ. Sci. Technol., 34, 5001-5006, 2000.

Pitts Jr., J. N., Atkinson, R., Sweetman, J. A., and Zielinska, B.: The gas-phase reaction of naphthalene with $\mathrm{N}_{2} \mathrm{O}_{5}$ to form nitronaphthalenes, Atmos. Environ., 19, 701-705, 1985.

Plum, C. N., Sanhueza, E., Atkinson, R., Carter, W. P. L., and Pitts Jr., J. N.: OH radical rate constants and photolysis rates of adicarbonyls, Environ. Sci. Technol., 17, 479-484, 1983.
Rinehart, L. R., Fujita, E. M., Chow, J. C., Magliano, K., and Zielinska, B.: Spatial Distribution of $\mathrm{PM}_{2.5}$ Associated Organic Compounds in the San Joaquin Valley, Atmos. Environ., 40, 290-303, 2006.

Robinson, A. L., Donahue, N. M., Shrivastava, M. K., Weitkamp, E. A., Sage, A. M., Grieshop, A. P., Lane, T. E., Pierce, J. R., and Pandis, S. N.: Rethinking organic aerosols: semivolatile emissions and photochemical aging, Science, 315, 1259-1262, 2007.

Sagebiel, J. C., Zielinska, B., Pierson, W. R., and Gertler, A. W.: Real-world emissions and calculated reactivities of organic species from motor vehicles, Atmos. Environ., 30, 2287-2296, 1996.

Samy, S.: Chemical Transformations of Complex Mixtures Relevant to Atmospheric Processes: Laboratory and Ambient Studies, Ph.D. Dissertation, 2009.

Sasaki, J., Aschmann, S. M., Kwok, E. S. C., Atkinson, R., and Arey, J.: Products of the gas-phase $\mathrm{OH}$ and $\mathrm{NO}_{3}$ radical-initiated reactions of naphthalene, Environ. Sci. Technol., 31, 3173-3179, 1997.

Seinfeld, J. H. and Pandis, S. N.: Atmospheric chemistry and physics: from air pollution to climate change, New York: Wiley, 1998

Song, C., Na, K., and Cocker III, D. R.: Impact of the hydrocarbon to $\mathrm{NO}_{\mathrm{x}}$ ratio on secondary organic aerosol formation, Environ. Sci. Technol., 39, 3143-3149, 2005.

Stern, J. E., Flagan, R. C., Grosjean, D., and Seinfeld, J. H.: Aerosol formation and growth in atmospheric aromatic hydrocarbon photooxidation, Environ. Sci. Technol., 21, 1224-1231, 1987.

Stroud, C. A., Makar, P. A., Michelangeli, D. V., Mozurkewich, M., Hastie, D. R., Barbu, A., and Humble, J.: Simulating organic aerosol formation during the photooxidation of toluene/ $\mathrm{NO}_{\mathrm{x}}$ mixtures: comparing the equilibrium and kinetic assumption, Environ. Sci. Technol., 38, 1471-1479, 2004.

Szidat, S., Jenk, T. M., Gaggeler, H. W., Synal, H. A., Fisseha, R., Baltensperger, U., Kalberer, M., Samburova, V., Reimann, S., Kasper-Giebl, A., and Hajdas, I.: Radiocarbon (14C)-deduced biogenic anthropogenic contributions to organic carbon (OC) of urban aerosols from Zurich, Switzerland, Atmos. Environ., 38, 4035-4044, 2004.

Volkamer, R., Platt, U., and Wirtz, K.: Primary and secondary glyoxal formation from aromatics: experimental evidence for the bicycloalkyl-radical pathway from benzene, toluene, and $p$ xylene, J. Phys. Chem. A, 105, 7865-7874, 2001.

Volkamer, R., Spietz, P., Burrows, J. P., and Platt, U.: Highresolution absorption cross-section of glyoxal in theUV-vis and IR spectral ranges, J. Photoch. Photobio. A, 172, 35-46, 2005.

Volkamer, R., Jimenez, J. L., Martini, F. S., Dzepina, K., Zhang, Q., Salcedo, D., Molina, L. T., Worsnop, D. R., and Molina, M. J.: Secondary organic aerosol formation from anthropogenic air pollution: Rapid and higher than expected, Geophys. Res. Lett., 33, L17811, doi:10.1029/2006GL026899, 2006.

Wang, L., Atkinson, R., and Arey, J.: Dicarbonyl products of the $\mathrm{OH}$ radical-initiated reactions of naphthalene and the $\mathrm{C} 1-$ and C2-alkylnaphthalenes, Environ. Sci. Technol., 41, 2803-2810, 2007.

Weitkamp, E. A., Sage, A. M., Pierce, J. R., Donahue, N. M., and Robinson, A. L.: Organic aerosol formation from photochemical oxidation of diesel exhaust in a smog chamber, Environ. Sci. Technol., 41, 6969-6975, 2007. 
Zielinska, B., Arey, J., Atkinson, R., and McElroy, P. A.: Formation of methylnitronaphthalenes from the gas-phase reactions of 1and 2-methylnaphthalene with $\mathrm{OH}$ radicals and $\mathrm{N}_{2} \mathrm{O}_{5}$ and their occurrence in ambient air, Environ. Sci. Technol., 23, 723-729, 1989a.

Zielinska, B., Arey, J., Atkinson, R., and Winer, A. M.: The nitroarenes of molecular weight 247 in ambient particulate samples collected in southern California, Atmos. Environ., 23, 223-229, 1989b.

Zielinska, B., Sagebiel, J., McDonald, J. D., Whitney, K., and Lawson, D. R.: Emission Rates and Comparative Chemical Composition from Selected In-Use Diesel and Gasoline-Fueled Vehicles, J. Air Waste Manage., 54, 1138-1150, 2004a.
Zielinska, B., Sagebiel, J., Arnott, W. P., Rogers, C. F., Kelly, K. E., Wagner, D. A., Lightly, J. S., Sarofim, A. F., and Palmer, G.: Phase and size distribution of polycyclic aromatic hydrocarbons in diesel and gasoline vehicle emissions, Environ. Sci. Technol., 38, 2557-2567, 2004b.

Zielinska, B.: Atmospheric transformation of diesel emissions, Exp. Toxicol. Pathol., 57, 31-42, 2005.

Zielinska, B., Samy, S., McDonald, J. D., and Seagrave, J.: Atmospheric transformation of diesel emissions, Final Report, Health Effects Institute, in press, 2009. 